\title{
Cinnamomum cassia Presl: A Review of Its Traditional Uses, Phytochemistry, Pharmacology and Toxicology
}

\author{
Chunling Zhang, Linhong Fan, Shunming Fan, Jiaqi Wang, Ting Luo, Yu Tang, Zhimin Chen * \\ and Lingying $\mathrm{Yu}$ * \\ School of Pharmacy, Chengdu University of Traditional Chinese Medicine, Chengdu 611137, China; \\ zhangchunling1997@163.com (C.Z.); fanlinhong1996@163.com (L.F.); fanshunming@stu.cdutcm.cn (S.F.); \\ kikiAPTX@163.com (J.W.); 1t530794033@163.com (T.L.); Ty593812828@163.com (Y.T.) \\ * Correspondence: czm346578767@163.com (Z.C.); yly111666@163.com (L.Y.); \\ Tel.: +86-028-61800213 (Z.C. \& L.Y.)
}

Received: 9 September 2019; Accepted: 23 September 2019; Published: 25 September 2019

\begin{abstract}
Cinnamomum cassia Presl is a tropical aromatic evergreen tree of the Lauraceae family, commonly used in traditional Chinese medicine. It is also a traditional spice, widely used around the world. This paper summarizes the achievements of modern research on C. cassia, including the traditional uses, phytochemistry, pharmacology and toxicology. In addition, this review also discusses some significant issues and the potential direction of future $C$. cassia research. More than 160 chemicals have been separated and identified from C. cassia. The main constituents of C. cassia are terpenoids, phenylpropanoids, glycosides, etc. Modern studies have confirmed that C. cassia has a wide range of pharmacological effects, including antitumour, anti-inflammatory and analgesic, anti-diabetic and anti-obesity, antibacterial and antiviral, cardiovascular protective, cytoprotective, neuroprotective, immunoregulatory effects, anti-tyrosinase activity and other effects. However, the modern studies of $C$. cassia are still not complete and more in-depth investigations need to be conducted in alimentotherapy, health product, toxicity and side effects, and more bioactive components and potential pharmacological effects need to be explored in the future.
\end{abstract}

Keywords: Cinnamomum cassia Presl; traditional uses; phytochemistry; pharmacology; toxicology

\section{Introduction}

Cinnamomum cassia Presl is an aromatic tree species belonging to the Lauraceae family. From the bark of its young branches, cinnamon is obtained, which is widely used all around the world for its fragrance and spicy flavor (Figure 1). It can be used not only as a daily condiment, but also as a raw material for medical products, and has high economic value. Cinnamomum cassia Presl is distributed in China, India, Vietnam, Indonesia and other countries; In China, the producing areas are mainly concentrated in Guangxi, Guangdong, Fujian and Hainan provinces. Cinnamomi cortex is the bark of C. cassia, which is often used as a seasoning and spices in the West. For instance, in America, Cinnamomi cortex is used as a food supplements, as a coumarin source of [1]. In Asia, Cinnamomi cortex is usually used as a drug. Cinnamomi cortex is a common traditional Chinese medicine in China. Since 1963, Cinnamomi cortex has been listed in the Pharmacopoeia of the People's Republic of China (CH.P), and there are more than 500 formulas containing Cinnamomi cortex used to treat various diseases, such as cardiovascular disease, chronic gastrointestinal disease, gynecological disorders and inflammatory disease [2-4]. Currently, a lot of studies have been done on the pharmacological and phytochemical of C. cassia, and more than 160 chemicals have been separated and identified from C. cassia. More and more studies have confirmed that $C$. cassia has a wide range of pharmacological effects, including antitumour, anti-inflammatory and analgesic, anti-diabetic and anti-obesity, antibacterial and antiviral, 
cardiovascular protective, cytoprotective, neuroprotective, immunoregulatory effects, anti-tyrosinase activity and other effects $[3,4]$. So far, the CH.P still recognizes Cinnamomi cortex as a common traditional Chinese medicine, and the content of cinnamaldehyde is used as an evaluation index for evaluating the quality of Cinnamomi cortex.
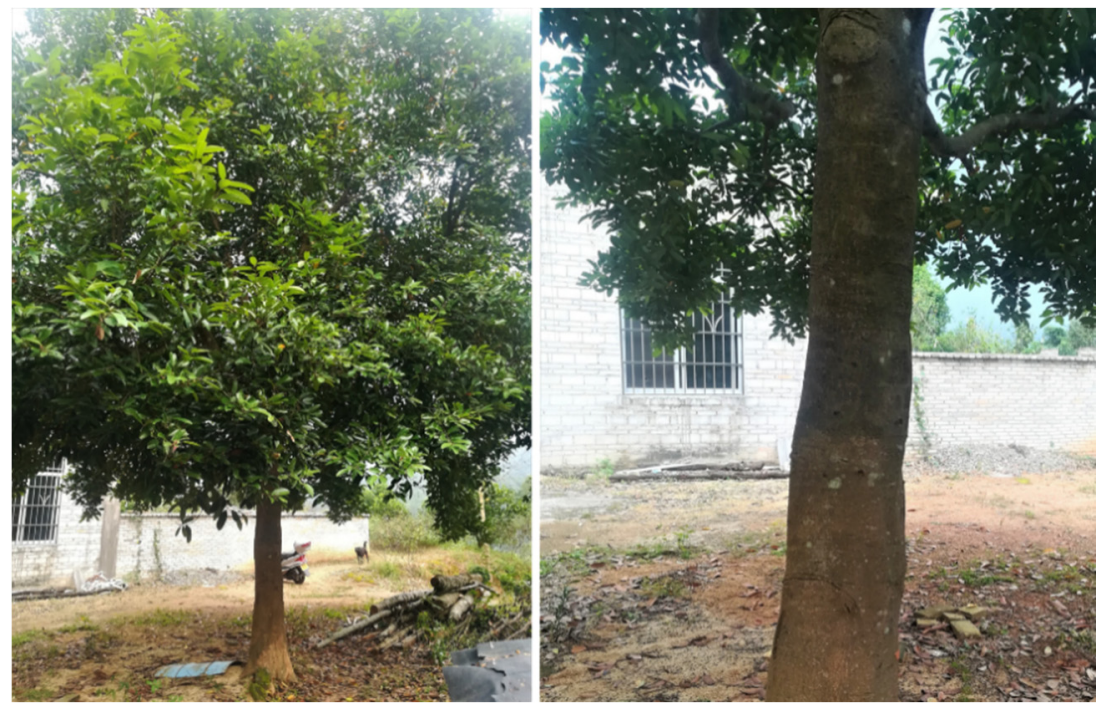

Figure 1. Cinnamomum cassia Presl.

\section{Traditional Usages}

As a traditional Chinese medicine Cinnamomum cassia Presl has a wide range of pharmacological activities and a long history of use as a drug. The earliest medicinal history of this plant was recorded in the Shennong Bencao Jing, which is the earliest and most important encyclopaedia of traditional Chinese medicine in the Eastern Han Dynasty (25-220 AD). In this classic, C. cassia was used for treating arthritis. In Mingyi Bielu, the function of C. cassia was analgesic. In Yaoxing Lun, which is another known traditional Chinese medicine classic, C. cassia was used for treating bellyaches and dysmenorrhea. In addition, C. cassia was also recorded in other famous traditional Chinese medicine books, such as Tangye Bencao, Bencao Gangmu, Bencao Jingshu, Bencao Huiyan, etc. Nowadays, C. cassia has become a common traditional Chinese medicine for treating nephropathy, dysmenorrhea, menoxenia and diabetes $[5,6]$. In order to be applied to clinic better, various dosage forms, such as pills, capsules, granules, oral liquid and so on, have been developed (Table 1).

Table 1. The traditional and clinical uses of C. cassia in China.

\begin{tabular}{cccc}
\hline Prescription Name & Main Component & Traditional and Clinical Uses & Reference \\
\hline Zi Shen Pills & $\begin{array}{c}\text { Anemarrhenae Rhizoma, } \\
\text { Phellodendri Chinensis Cortex, Cinnamomi Cortex }\end{array}$ & $\begin{array}{c}\text { Treating dysuria due to } \\
\text { accumulation heat in bladder }\end{array}$ \\
\hline Gui Fu Li Zhong Pills & $\begin{array}{c}\text { Cinnamomi Cortex, } \\
\text { [coniti Lateralis Radix Praeparata, Codonopsis Radix, } \\
\text { Glycyrrhizae Radix Et Rhizoma, Atractylodis, } \\
\text { Macrocephalae Rhizoma, Roasted Ginger }\end{array}$ & $\begin{array}{c}\text { Curing abdominal pain, diarrhoea } \\
\text { and vomiting due to deficient cold } \\
\text { of spleen and stomach, }\end{array}$ \\
\hline Ding Gui Wen Wei San & Caryophylli Flos, Cinnamomi Cortex & $\begin{array}{c}\text { Curing abdominal pain caused by } \\
\text { cold syndrome }\end{array}$ \\
\hline Jian Wei Shi Wei Pills & $\begin{array}{c}\text { Granati Pericarpium, Amomi Fructus Rotundus, } \\
\text { Chebulae Fructus, Cinnamomi Cortex, Piperis Fructus, } \\
\text { Kaempferiae Rhizoma, Piperis Longi Fructus }\end{array}$ & $\begin{array}{c}\text { Curing cacochylia, } \\
\text { gasteremphraxis, vomiting and } \\
\text { diarrhea }\end{array}$ \\
\hline Qi Wei Wei Tong \\
Capsules & $\begin{array}{c}\text { Aucklandiae Radix, Piperis Longifructus, Alpiniae } \\
\text { Officinaru Mrhizoma, Galli Gigerii Endothelium } \\
\text { Corneum, Euodiae Fructus, Cinnamomi Cortex }\end{array}$ & $\begin{array}{c}\text { Treating diarrhoea, vomiting, poor } \\
\text { appetite, gastroduodenal ulcer } \\
\text { and superficial gastritis }\end{array}$ \\
\hline
\end{tabular}


Table 1. Cont.

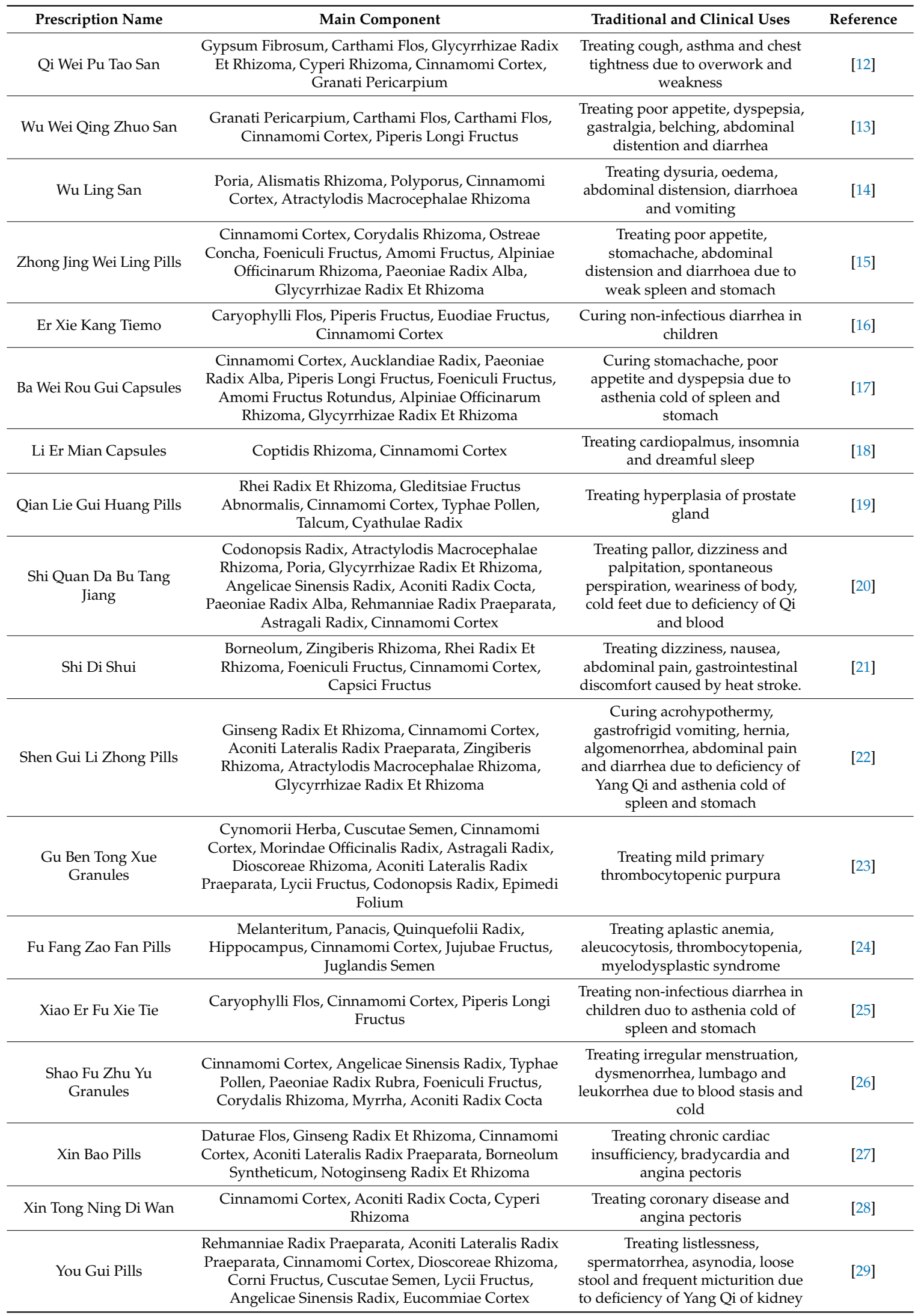


Table 1. Cont.

\begin{tabular}{|c|c|c|c|}
\hline Prescription Name & Main Component & Traditional and Clinical Uses & Reference \\
\hline $\begin{array}{c}\text { Shi Wei Fu Zheng } \\
\text { Granules }\end{array}$ & $\begin{array}{c}\text { Ginseng Radix Et Rhizoma, Rehmanniae Radix } \\
\text { Praeparata, Atractylodis Macrocephalae Rhizoma, } \\
\text { Astragali Radix, Poria, Paeoniae Radix Alba, Angelicae } \\
\text { Sinensis Radix, Cinnamomi Cortex, Glycyrrhizae } \\
\text { Radix Et Rhizoma, Aconiti Radix Cocta }\end{array}$ & $\begin{array}{l}\text { Treating aleucocytosis, decrease of } \\
\text { immune function caused by tumor } \\
\text { radiotherapy and chemotherapy }\end{array}$ & [30] \\
\hline Ba Wei Shen Qi Pills & $\begin{array}{c}\text { Rehmanniae Radix Praeparata, Dioscoreae Rhizoma, } \\
\text { Poria, Schisandrae Chinensis Fructus, Cinnamomi } \\
\text { Cortex, Alismatis Rhizoma, Aconiti Lateralis Radix } \\
\text { Praeparata, Moutan Cortex }\end{array}$ & $\begin{array}{c}\text { Treating edematous, cough, } \\
\text { dyspnea, frequent micturition and } \\
\text { loose stool duo to deficiency Yang } \\
\text { of kidney }\end{array}$ & [31] \\
\hline Dai Wen Jiu Gao & $\begin{array}{l}\text { Capsici Fructus, Cinnamomi Cortex, Zineiberis } \\
\text { Rhizoma Rrcens, Cinnamon Oil }\end{array}$ & $\begin{array}{l}\text { Curing chronic rheumatic arthritis, } \\
\text { chronic gastroenteritis }\end{array}$ & [32] \\
\hline
\end{tabular}

\section{Phytochemistry}

There have been a lot of studies about the phytochemistry of C. cassia, and more than 160 components have been separated and identified from the plant. Among them, terpenoids are the most abundant phytochemicals in C. cassia, and phenylpropanoids are the bioactive components, among which cinnamaldehyde is considered as the representative component of this plant, and the indicator component stipulated in the CH.P. In addtion to the chemical components found in the bark, the chemical components of other parts of C. cassia, including leaves and twigs, were also reported. The identified compounds are listed in this section and the corresponding structures are also comprehensively presented (Table 2, Figures 2-9).

Table 2. Chemical constituents isolated from C. cassia.

\begin{tabular}{|c|c|c|c|c|}
\hline Classification & No. & Chemical Component & Part of Plant & Ref. \\
\hline \multirow{38}{*}{ Terpenoids } & 1 & endo-borneol & Twig & [33] \\
\hline & 2 & $(-)$ - $\alpha$-terpineol & Twig & [33] \\
\hline & 3 & 1-terpineol & Leaves & [34] \\
\hline & 4 & cis- $\beta$-terpineol & Leaves & [34] \\
\hline & 5 & $\alpha$-terpineol & Bark, leaves & {$[34,35]$} \\
\hline & 6 & $\beta$-bisabolene & Bark, twig & {$[33,36]$} \\
\hline & 7 & $\alpha$-bisabolol & Bark, twig & {$[33,36]$} \\
\hline & 8 & linalool & Bark & [36] \\
\hline & 9 & camphene & Bark & {$[36]$} \\
\hline & 10 & $\beta$-pinene & Bark & [36] \\
\hline & 11 & camphor & Bark & [36] \\
\hline & 12 & geranyl acetate & Bark & [36] \\
\hline & 13 & cinnzeylanol & Bark & [37] \\
\hline & 14 & anhydrocinnzeylanol & Bark & [37] \\
\hline & 15 & cinnzeylanone & Bark & [37] \\
\hline & 16 & 2,3-dehydroanhydrocinnzeylanine & Bark & [38] \\
\hline & 17 & 1-acetylcinncassiol A & Bark & [38] \\
\hline & 18 & anhydrocinnzeylanine & Bark & [38] \\
\hline & 19 & 18S-cinncassiol A 19-O- $\beta$-D-glucopyranoside & Bark & [38] \\
\hline & 20 & $18 R$-cinncassiol A $19-O-\beta$-D-glucopyranoside & Bark & [38] \\
\hline & 21 & 18-hydroxycinnzeylanine & Bark & [38] \\
\hline & 22 & cinncassiol A & Bark & [38] \\
\hline & 23 & cinncassiol B & Bark & [38] \\
\hline & 24 & cinncassiol C & Bark & [38] \\
\hline & 25 & cinncassiol D & Bark & [38] \\
\hline & 26 & cinncassiol E & Bark & [38] \\
\hline & 27 & cinncassiol F & Bark & [39] \\
\hline & 28 & cinncassiol G & Bark & [39] \\
\hline & 29 & 16-O- $\beta$-D-glucopyranosyl-19-deoxycinncassiol G & Bark & [39] \\
\hline & 30 & cinnacasol & Bark & [39] \\
\hline & 31 & perseanol & Bark & [39] \\
\hline & 32 & cinncassiol $\mathrm{D}_{1}$ & Bark & [39] \\
\hline & 33 & $\mathrm{D}_{1}$ glucoside & Bark & [39] \\
\hline & 34 & $\mathrm{D}_{2}$ glucoside & Bark & [39] \\
\hline & 35 & $\mathrm{D}_{3}$ glucoside & Bark & [39] \\
\hline & 36 & $\mathrm{D}_{4}$ glucoside & Bark & [39] \\
\hline & 37 & 18-hydroxyperseanol & Bark & [39] \\
\hline & 38 & curcumene & Twig & [33] \\
\hline
\end{tabular}


Table 2. Cont.

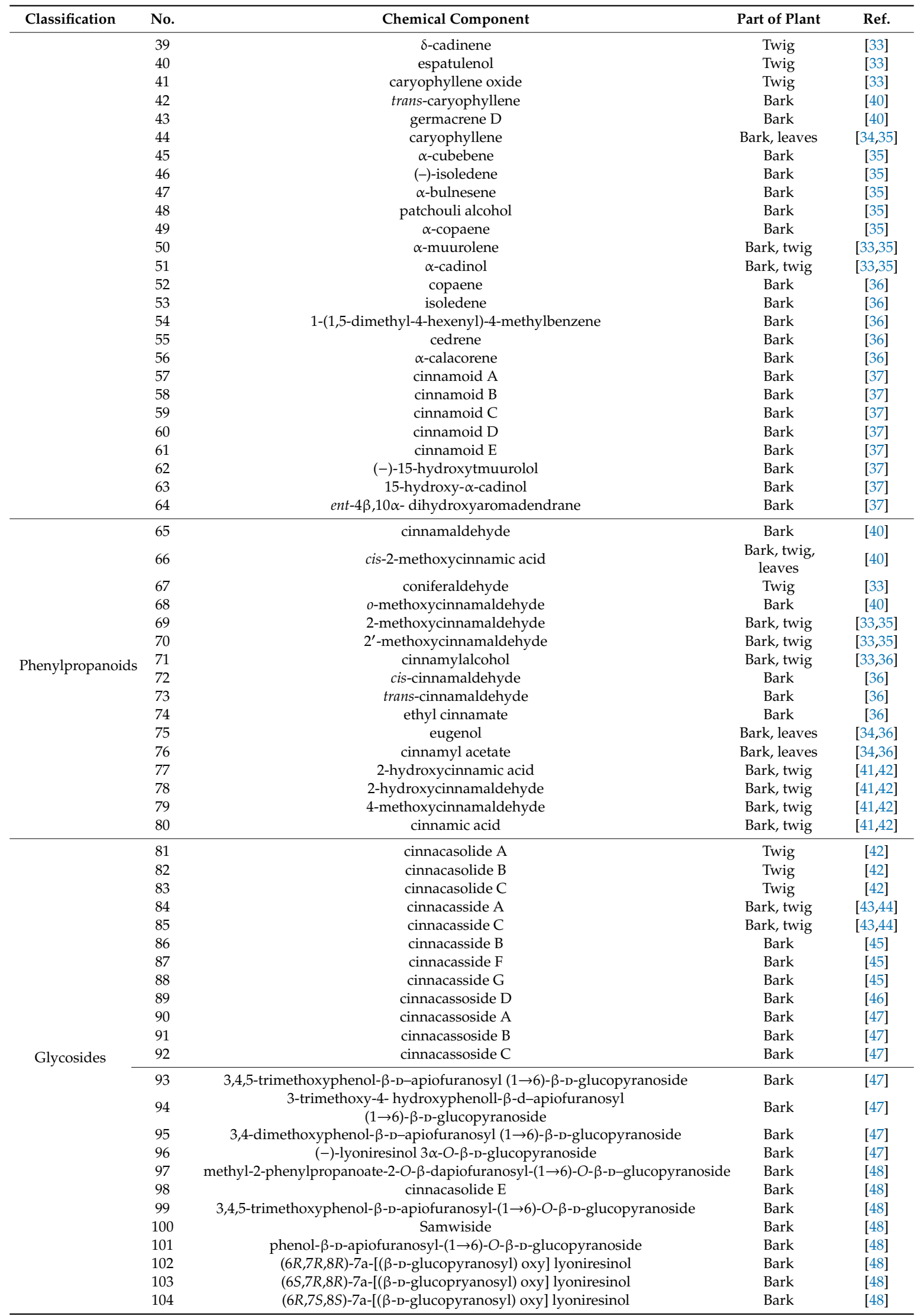


Table 2. Cont.

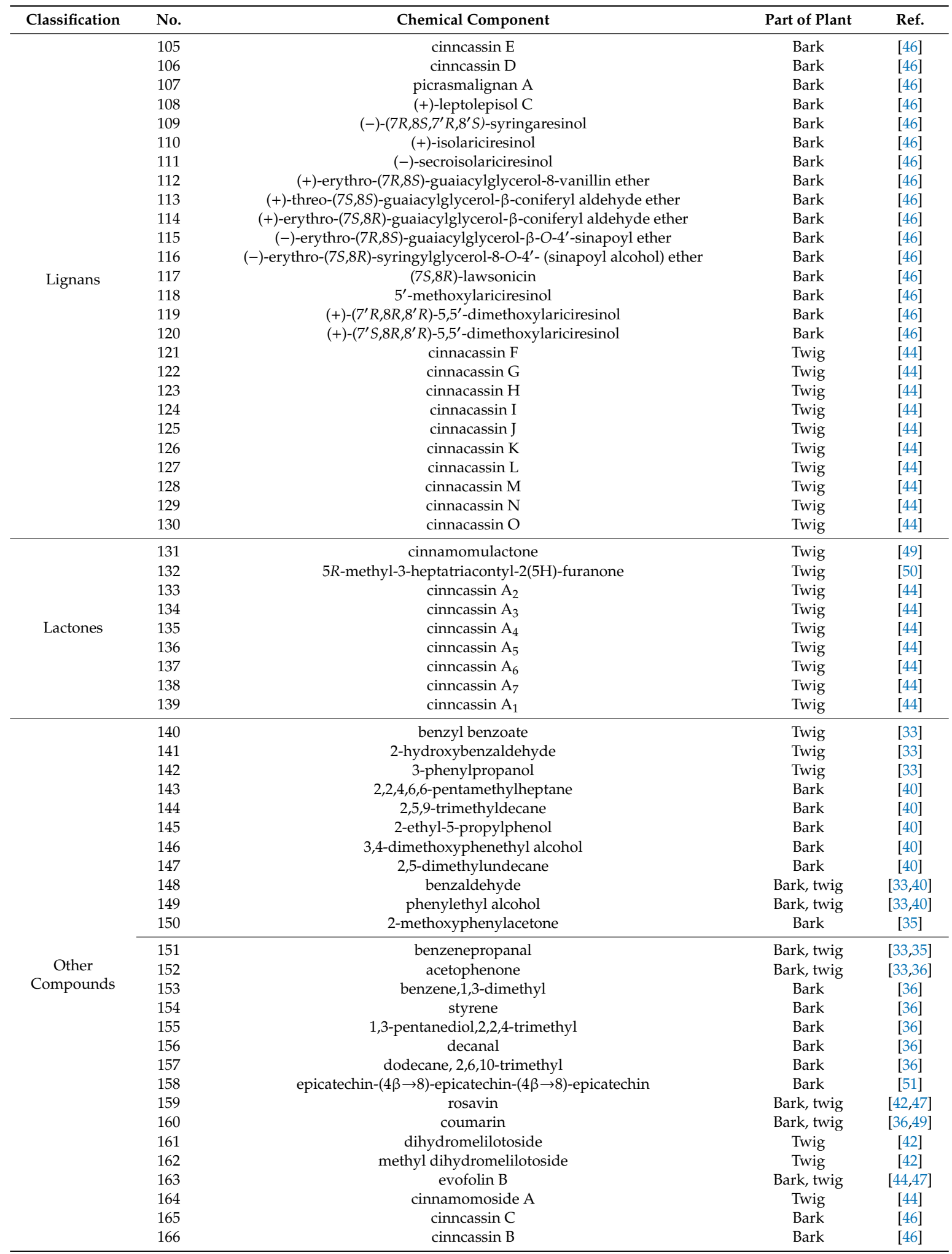

\subsection{Terpenoids}

Terpenoids are the main compounds in essential oil of $C$. cassia (EOC). Plant essential oils have a lot of important biological functions and physiological activities. Essential oils with strong antibacterial, 
antiviral, antitumor and anti-inflammatory effects are the main characteristic components of the Lauraceae [52-54]. The terpenoids in EOC are monoterpenes, diterpenes and sesquiterpenes.

So far, 12 monoterpenes have been found in C. cassia. Among them, endo-borneol (1) and (-)- $\alpha$-terpineol (2) were isolated from essential oil of twigs of $C$. cassia (EOTC) [33]. Moreover, 1-terpineol (3) and cis- $\beta$-terpineol (4) were isolated from essential oil of leaves of $C$. cassia (EOLC) [34]. Other compounds also isolated and identified from the bark, leaves and twigs of $C$. cassia, include $\alpha$-terpineol (5) [34,35], $\beta$-bisabolene (6), $\alpha$-bisabolol (7) [33,36], linalool (8), camphene (9), $\beta$-pinene (10), camphor (11) and geranyl acetate (12) [36], The corresponding structures of these essential oil components isolated from C. cassia are shown in Figure 2.
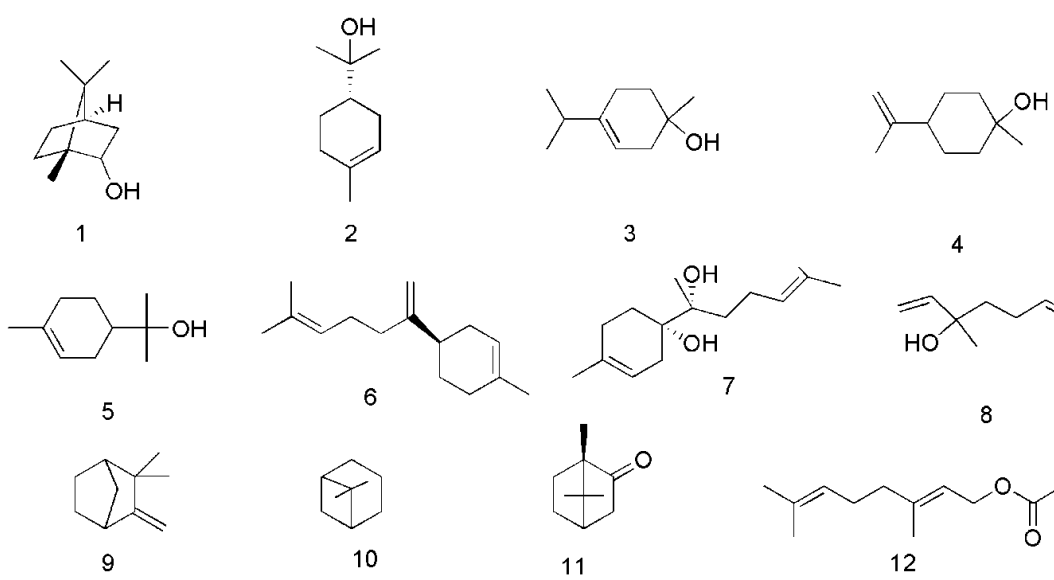

Figure 2. Chemical structures of the monoterpenes in C. cassia.

Diterpenoids are also important active constituents found in C. cassia. To date, 25 diterpenoids have been reported in this plant. These compounds are potentially effective natural immunomodulators in the treatment of autoimmune diseases, tumorigenesis, and chronic inflammatory diseases [39]. The diterpenoids isolated from the barks of $C$. cassia include cinnzeylanol (13), anhydrocinnzeylanol (14), cinnzeylanone (15) [37], 2,3-dehydroanhydrocinnzeylanine (16), 1-acetylcinncassiol A (17), anhydrocinnzeylanine (18), 18S-cinncassiol A 19-O- $\beta$-D-glucopyranoside (19), 18R-cinncassiol A 19-O- $\beta$-D-glucopyranoside (20), 18-hydroxycinnzeylanine (21), cinncassiol A (22), cinncassiol B (23), cinncassiol C (24), cinncassiol D (25), cinncassiol E (26) [38], cinncassiol F (27), cinncassiol G (28), 16-O- $\beta$-D-glucopyranosyl-19-deoxycinncassiol G (29), cinnacasol (30), perseanol (31), cinncassiol $D_{1}$ (32), $\mathrm{D}_{1}$ glucoside (33), $\mathrm{D}_{2}$ glucoside (34), $\mathrm{D}_{3}$ glucoside (35), $\mathrm{D}_{4}$ glucoside (36), 18-hydroxyperseanol (37) [39]. The corresponding structures of these essential oil components isolated from C. cassia are shown in Figure 3.
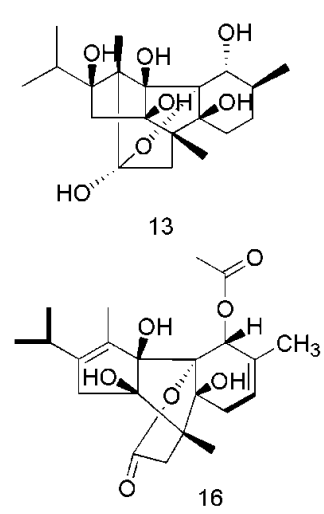

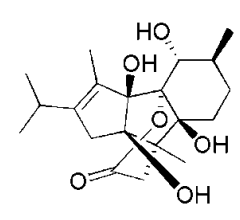

14

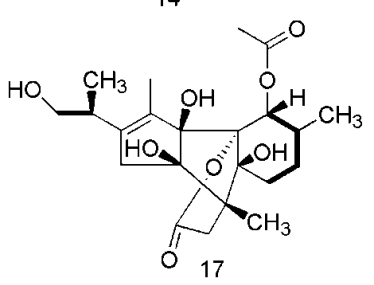

Figure 3. Cont.

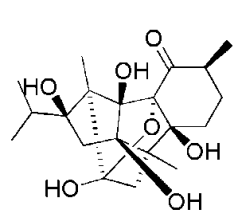

15

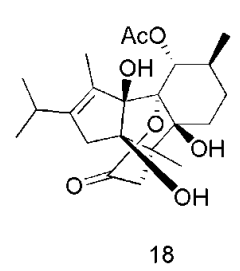

18 


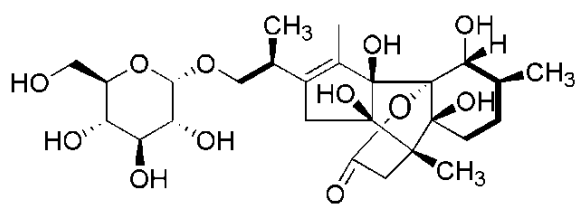

19

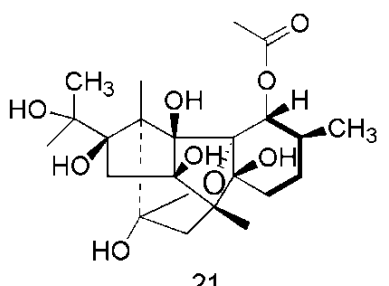

21

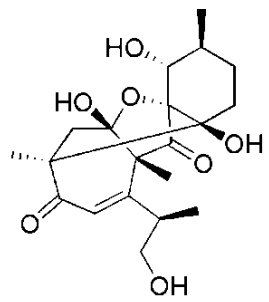

24

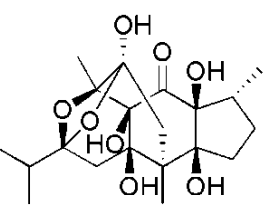

27

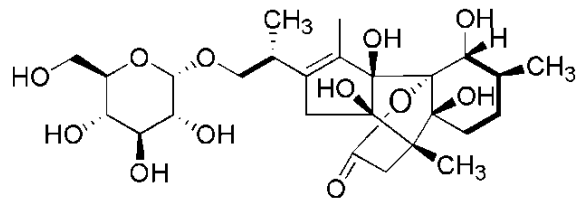

20

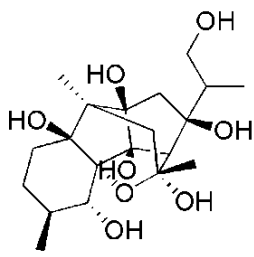

23

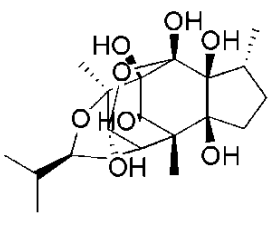

26

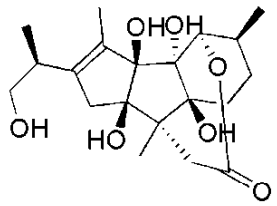

30

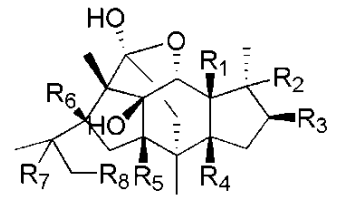

$\begin{array}{llllllll}R_{1} & R_{2} & R_{3} & R_{4} & R_{5} & R_{6} & R_{7} & R_{8}\end{array}$

$31 \mathrm{OH} \mathrm{H} \mathrm{H} \mathrm{OH} \mathrm{OH} \mathrm{H} \mathrm{H} \mathrm{H}$

$32 \mathrm{HOH} \mathrm{H} \mathrm{H} \mathrm{H} \mathrm{H} \mathrm{HOH}$

$33 \mathrm{H} \mathrm{OH} \mathrm{H} \quad \mathrm{H} \quad \mathrm{H} \quad \mathrm{H} H ~ O-G l c$

$34 \mathrm{HOH} \mathrm{H}$ OH H H HOH

$35 \mathrm{H} \mathrm{H} \mathrm{H} \mathrm{OH} \mathrm{H} \mathrm{H} \mathrm{H} \mathrm{OH}$

$36 \mathrm{H} \mathrm{H} \mathrm{O}-\mathrm{GlCOH} \mathrm{H} \mathrm{H} \mathrm{H} \mathrm{H}$

Figure 3. Chemical structures of the diterpenoids in C. cassia.

Sesquiterpenoids are another class of bioactive constituents found in C. cassia. Twenty seven sesquiterpenoids, including curcumene (38), $\delta$-cadinene (39), espatulenol (40), caryophyllene oxide (41) [33], trans-caryophyllene (42), germacrene D (43) [40], caryophyllene (44) [34,35], $\alpha$-cubebene (45), (-)-isoledene (46), $\alpha$-bulnesene (47), patchouli alcohol (48), $\alpha$-copaene (49) [35], $\alpha$-muurolene (50), $\alpha$-cadinol (51) [33,35], copaene (52), isoledene (53), 1-(1,5-dimethyl-4-hexenyl)-4-methylbenzene (54), cedrene (55), $\alpha$-calacorene (56) [36], cinnamoid A (57), cinnamoid B (58), cinnamoid C (59), cinnamoid D (60), cinnamoid E (61), (-)-15-hydroxy-tmuurolol (62), 15-hydroxy- $\alpha$-cadinol (63) and ent-4 $\beta, 10 \alpha$-dihydroxyaromadendrane (64) are reported from this plant [37]. The corresponding structures of these sesquiterpenoids are shown in Figure 4. 
<smiles>CC(C)=CCCC(C)c1ccc(C)cc1</smiles>

38<smiles>C=C1CC/C=C(/C)CC[C@@H]2[C@H]1CC2(C)C</smiles>

42<smiles>CC1CCC2=C1[C@H](C(C)C)CCC[C@H]2C</smiles>

46

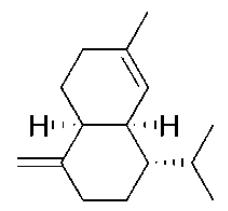

50<smiles>CC(C)=CCC[C@H](C)c1ccc(C)cc1</smiles>

54

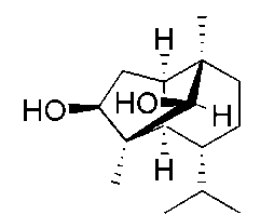

57

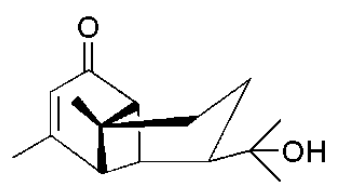

61

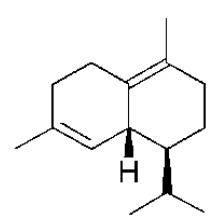

39<smiles>CC1CC=C[C@H](C)CCC(C(C)C)CC1</smiles>

43<smiles>C=C1CC[C@H]2O[C@H]2CC[C@@H]2[C@H](CC2(C)C)[C@H]1C</smiles>

47<smiles>CC1=CC2C(CC1)C(C)(O)CCC2(C)C</smiles>

51<smiles>C=C1CC[C@@H](C)[C@@H]2[C@@H](C)C(C)(C#N)[C@@H]2CC1</smiles><smiles>C/C1=C/CC/C(C)=C/CC(C)(C)/C=C/C1</smiles>

44

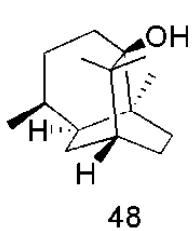

48<smiles>CC1=C[C@H]2C[C@H]3C(C(C)C)CCC2(C)[C@H]13</smiles>

52

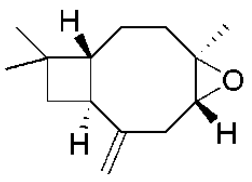

41<smiles>CC1=CC[C@]23C[C@H](C)CC[C@@H](C(C)C)[C@H]2C[C@H]3C1</smiles>

45<smiles>CC1=CC[C@H]2C[C@H](C(C)C)CC[C@@H]12</smiles>

49<smiles>CC1CCC2=C1C[C@H](C(C)C)CC[C@H]2C</smiles>

53<smiles>CC1=CC[C@H](C(C)C)c2cc(C)ccc21</smiles>

56

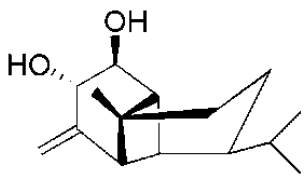

60

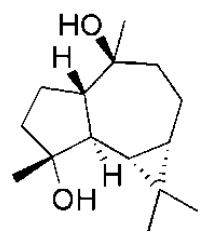

64

Figure 4. Chemical structures of the sesquiterpenoids in C. cassia.

\subsection{Phenylpropanoids}

Phenylpropanoids are the main bioactive components of C. cassia. In 2013, cinnamaldehyde (65) and cis-2-methoxycinnamic acid (66) were isolated from essential oil of bark of C. cassia (EOBC), their contents being $42.37 \%$ and $43.06 \%$, respectively [40]. In addition, coniferaldehyde (63) [33], o-methoxycinnamaldehyde (68) [40], 2-methoxycinnamaldehyde (69), 2'-methoxycinnamaldehyde 
(70) [33,35], cinnamylalcohol (71) [33,36], cis-cinnamaldehyde (72), trans-cinnamaldehyde (73), ethyl cinnamate (74) [36], eugenol (75), cinnamyl acetate (76) [34,36], 2-hydroxycinnamic acid (77), 2-hydroxycinnamaldehyde (78), 4-methoxycinnamaldehyde (79), and cinnamic acid (80) [41,42] were isolated from different parts of $C$. cassia. The corresponding structures of these phenylpropanoids are shown in Figure 5.<smiles>O=C/C=C/c1ccccc1</smiles>

65<smiles>COc1cccc(/C=C/C=O)c1</smiles>

69<smiles>COc1ccccc1/C=C/C(=O)O</smiles>

66

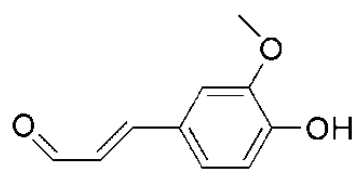

67<smiles>COc1ccccc1/C=C/C=O</smiles>

68<smiles>COc1ccccc1/C=C/C=O</smiles>

70<smiles>OC/C=C/c1ccccc1</smiles>

71<smiles>O=C/C=C/c1ccccc1</smiles>

72<smiles>O=C/C=C/c1ccccc1</smiles>

73<smiles>O=C(O)/C=C/c1ccccc1O</smiles>

77<smiles>[Y4]/C(=C\C(=O)OCC)c1ccccc1</smiles>

74<smiles>O=C/C=C/c1ccccc1O</smiles>

78<smiles>C=CCc1ccc(O)c(OC)c1</smiles>

75<smiles>COc1ccc(/C=C/C=O)cc1</smiles>

79<smiles>CC(=O)OC/C=C/c1ccccc1</smiles>

76

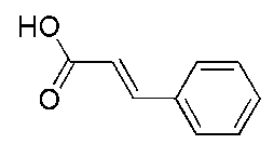

80

Figure 5. Chemical structures of the phenylpropanoids in C. cassia.

\subsection{Glycosides}

So far, three glycosides have been isolated from the twigs of $C$. cassia, including cinnacasolide A (81), cinnacasolide B (82) and cinnacasolide C (83) [42], two glycosides isolated from the twigs and leaves of C. cassia include cinnacasside A (84) and cinnacasside C (85) [43,44].

Furthermore, 19 glycosides had been isolated from the barks of $C$. cassia, including cinnacasside B (86), cinnacasside F (87), cinnacasside G (88) [45], cinnacassoside D (89) [46], cinnacassoside A (90), cinnacassoside B (91), cinnacassoside C (92), 3,4,5-trimethoxyphenol- $\beta$-D-apiofuranosyl $(1 \rightarrow 6)$ - $\beta$-D-glucopyranoside (93), 3-trimethoxy-4-hydroxyphenol- $\beta$-D-apiofuranosyl( $1 \rightarrow 6)-\beta$-Dglucopyranoside (94), 3,4-dimethoxy-phenol- $\beta$-D-apiofuranosyl ( $1 \rightarrow 6)$ - $\beta$-D-glucopyranoside (95), (-)-lyoniresinol $3 \alpha-O-\beta$-D-gluco- pyranoside (96) [47], methyl 2-phenylpropanoate-2-O- $\beta$-Dapiofuranosyl-( $(\rightarrow 6)$-O- $\beta$-D-gluco-pyranoside (97), cinnacasolide E (98), 3,4,5-trimethoxyphenol- $\beta$-Dapiofuranosyl-( $(1 \rightarrow 6)$-O- $\beta$-D-glucopyranoside (99), samwiside (100), phenol- $\beta$-D-apiofuranosyl-( $1 \rightarrow 6)$ $O$ - $\beta$-D-glucopyranoside (101), (6R,7R,8R)-7a-[( $\beta$-D-glucopyranosyl)oxy]lyoniresinol (102), $(6 S, 7 R, 8 R)$ -7a-[( $\beta$-D-gluco-pyranosyl)oxy]lyoniresinol (103), (6R,7S,8S)-7a-[( $\beta$-D-glucopyranosyl)-oxy]lyoniresinol (104) [48]. The corresponding structures of these glycosides isolated from C. cassia are shown in Figure 6. 


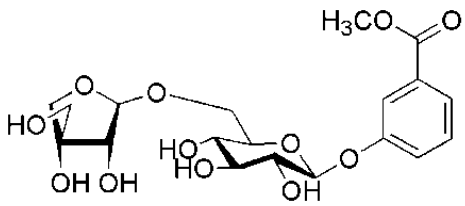

81<smiles>COC(=O)Cc1cc(O)cc(/C=C/[C@@]2(C)CC[C@@H](C(C)(C)O)O2)c1CO[C@H]1O[C@H](O)[C@@H](O)[C@H](O)[C@H]1O</smiles>

8411 S $14 R$

$8511 \mathrm{R} 14 \mathrm{R}$

$8611 \mathrm{~S} 14 \mathrm{R}$

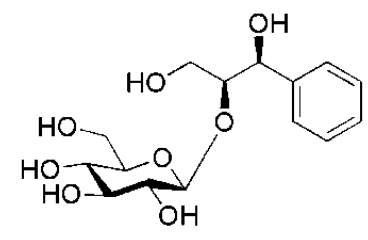

89

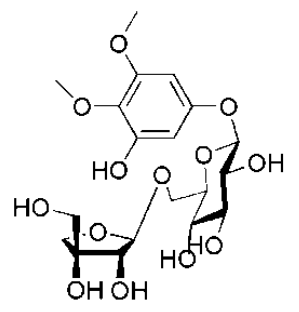

92

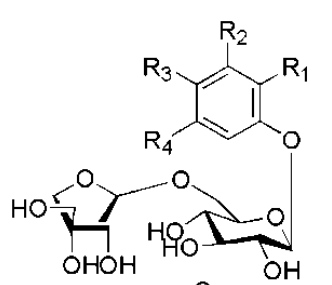

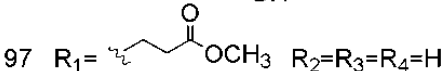

$98 \quad R_{1}=R_{3}=\mathrm{OCH}_{3} \quad \mathrm{R}_{2}=\mathrm{R}_{4}=\mathrm{H}$

$99 \mathrm{R}_{1}=\mathrm{H} \mathrm{R}_{2}=\mathrm{R}_{3}=\mathrm{R}_{4}=\mathrm{OCH}_{3}$

$100 R_{1}=R_{2}=R_{3}=R_{4}=H$<smiles>[R7]C=Cc1ccccc1[R2]</smiles>

$82 \mathrm{R}_{1}=\mathrm{CH}_{2} \mathrm{OH} \mathrm{R} \mathrm{R}_{2}=$ OGlc-Api<smiles>COC(=O)Cc1cc(O)cc(C[C@@H](O)[C@]2(C)CC[C@H](C(C)(C)O)O2)c1O[C@H]1O[C@@H](O)[C@H](O)[C@H](O)[C@H]1O</smiles>

87

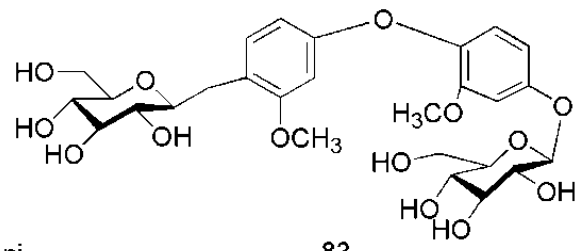

83

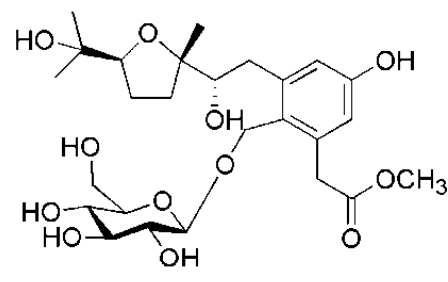

88<smiles>COc1cc(CC(CO)C(COC2OC(O)C(O)C(O)C(O)C(O)C2O)C(O)c2ccc(O)c(OC)c2)ccc1O</smiles>

90

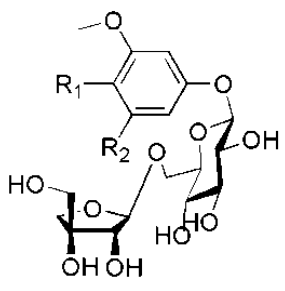

$93 \mathrm{R}_{1}=\mathrm{OCH}_{3} \mathrm{R}_{2}=\mathrm{H}$

$94 \mathrm{R}_{1}=\mathrm{OCH}_{3} \mathrm{R}_{2}=\mathrm{OCH}_{3}$

$95 \mathrm{R}_{1}=\mathrm{OH} \quad \mathrm{R}_{2}=\mathrm{H}$

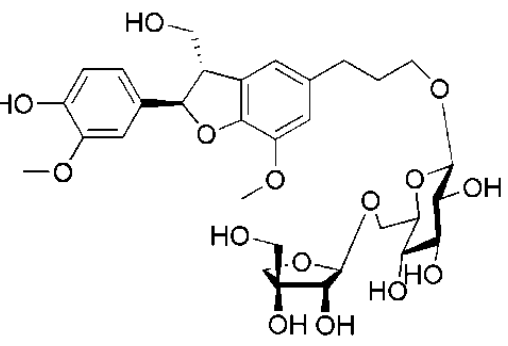

91

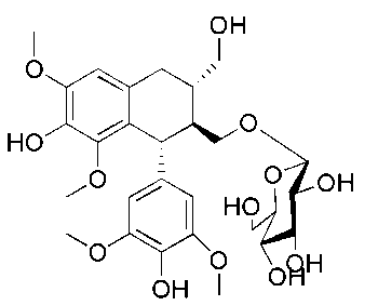<smiles>COc1cc(CCCOC2OC3OC4OC(O)(OC4O)C(O)C3OC2O)cc2c1CC[C@H]2CO</smiles><smiles>COc1ccccc1O</smiles>

101

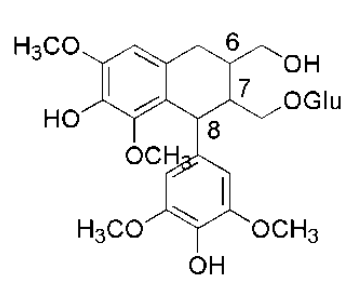

102 6R, 7S, 8S

103 6R, 7R, 8R

104 6S, 7R, 8S

Figure 6. Chemical structures of the glycosides in C. cassia. 


\subsection{Lignans}

In recent years, lignanoids have been found in C. cassia, and 26 lignanoids have been isolated from it, which are shown in Figure 7. In 2016, cinncassin E (105) was found from the bark of C. cassia and its nitric oxide inhibitory activity has been demonstrated. Meanwhile, the lignanoids isolated from the twigs of C. cassia include cinncassin D (106), picrasmalignan A (107), (+)-leptolepisol C (108), (-)-(7R,8S, $\left.7^{\prime} R, 8^{\prime} S\right)$-syringaresinol (109), (+)-isolariciresinol (110), (-)-secroisolariciresinol (111), (+)-erythro-(7R,8S)-guaiacylglycerol-8-vanillin ether (112), (+)-threo-(7S,8S)-guaiacylglycerol- $\beta$-coniferyl aldehyde ether (113), (+)-erythro-(7S,8R)-guaiacylglycerol- $\beta$-coniferyl aldehyde ether (114), (-)-erythro-(7R,8S)-guaiacylglycerol- $\beta$-O- $4^{\prime}$-sinapoyl ether (115), (-)-erythro-(7S,8R)-syringylglycerol8-O-4' -(sinapoyl alcohol) ether (116), (7S,8R)-lawsonicin (117), 5'-methoxylariciresinol (118), (+)-( $\left(7^{\prime} R, 8 R, 8^{\prime} R\right)-5,5^{\prime}$-dimethoxylariciresinol (119), $\quad(+)-\left(7^{\prime} S, 8 R, 8^{\prime} R\right)-5,5^{\prime}$-dimethoxylariciresinol (120) [46]. The lignanoids isolated from the leaves of $C$. cassia include cinnacassin $F(121)$, cinnacassin G (122), cinnacassin H (123), cinnacassin I (124), cinnacassin J (125), cinnacassin K (126), cinnacassin L (127), cinnacassin M (128), cinnacassin N (129) and cinnacassin O (130) [44].<smiles>COc1cc(/C=C/C=O)ccc1OC(CO)C(O)c1cc(OC)c(O)c(OC)c1</smiles><smiles>COc1cc(/C=C/C=O)c2c(c1)O[C@H](c1cc(OC)c3c(c1)[C@@H](CO)[C@@H](c1ccc(O)c(OC)c1)O3)[C@@H]2CO</smiles>

107<smiles>COc1cc([C@@H]2OC[C@H]3[C@H]2CO[C@H]3c2cc(OC)c(O)c(OC)c2)cc(OC)c1O</smiles><smiles>COc1cc(CC(CO)C(CO)Cc2ccc(O)c(OC)c2)ccc1O</smiles><smiles>COc1cc(OC)c2c(c1)O[C@H](c1cc(OC)c3c(c1)C(CO)[C@@H](c1ccc(O)c(OC)c1)O3)[C@H]2CO</smiles><smiles>COc1cc(C(CO)C(O)c2cc(OC)c3c(c2)[C@H](CO)[C@@H](c2ccc(O)c(OC)c2)O3)ccc1O</smiles><smiles>COc1cc([C@H]2c3cc(O)c(OC)cc3C[C@@H](CO)[C@H]2CO)ccc1O</smiles>

110<smiles>COc1cc([C@@H](O)[C@@H](CO)Oc2ccc(C=O)cc2OC)ccc1O</smiles>

Figure 7. Cont. 


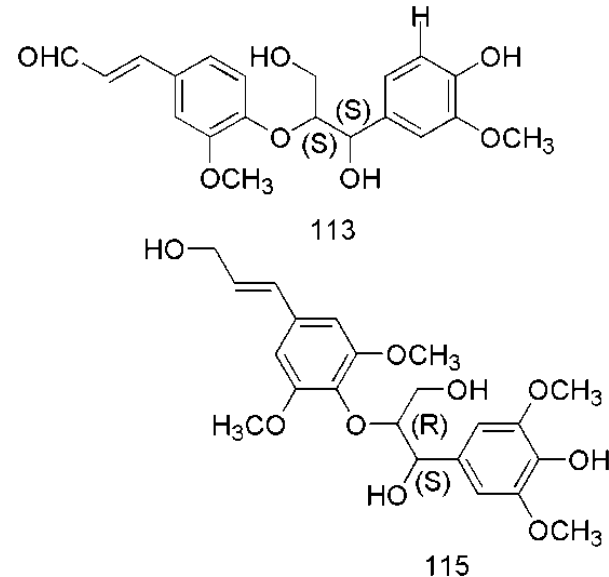<smiles>COc1cc([C@@H]2Oc3c(OC)cc(CCCO)cc3[C@@H]2CO)ccc1O</smiles><smiles>COc1cc(C[C@@H]2CO[C@H](c3cc(OC)c(O)c(OC)c3)[C@H]2CO)cc(OC)c1O</smiles><smiles>COc1cc([C@@H]2OC[C@H]3[C@H](c4cc(OC)c(O)c(OC)c4)OC[C@@H]32)cc(O)c1O</smiles>
121
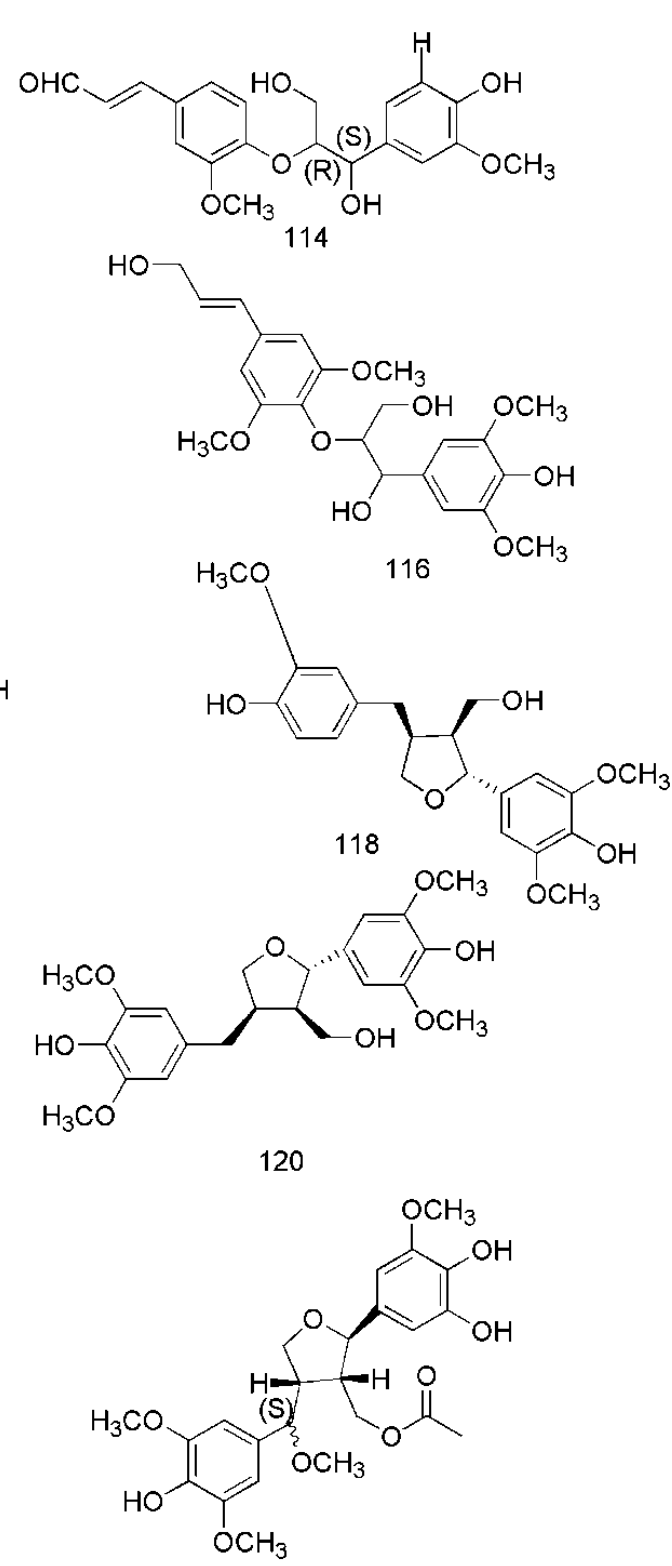

122

Figure 7. Cont. 
<smiles>COc1cc([C@@H]2OC[C@@H](C)[C@@H](c3cc(OC)c(O)c(OC)c3)[C@@H]2COC(C)=O)cc(O)c1O</smiles>

123<smiles>OC1c2ccccc2OC(OC/C=C/c2ccccc2)[C@@H]1O</smiles>

126<smiles>C=CCc1cc(O)c(-c2c(OC)cc(C3(CO)OO3)cc2OC)c(OC)c1</smiles>

124<smiles>C[C@H]1CO[C@@H](/C=C/c2ccccc2)O[C@H]1c1ccccc1</smiles>

127<smiles>O[C@H]1O[C@H](/C=C/c2ccccc2)[C@H](c2ccccc2)[C@H]1O</smiles>

128<smiles></smiles>

129<smiles>COc1cc(O)c(CC2OC2c2ccc(OC)c(OC)c2)c(O)c1</smiles>

130

Figure 7. Chemical structures of the lignans in C. cassia.

\subsection{Lactones}

In 2017, cinnamomulactone (131), isolated from the twigs of $C$. cassia, was found to have an effect against matrix metalloproteinase (MMP) [49]. Later, 5R-methyl-3-heptatriacontyl-2(5H)-furanone (132) [50], cinncassin $A_{2}$ (133), cinncassin $A_{3}$ (134), cinncassin $A_{4}$ (135), cinncassin $A_{5}$ (136), cinncassin $A_{6}$ (137), cinncassin $A_{7}$ (138) and cinncassin $A(139)$ were found from the twigs of $C$. cassia [44]. The corresponding structures of these lactones isolated from C. cassia are shown in Figure 8.<smiles>COc1cc([C@H]2COC(=O)[C@H]2c2ccc(O)cc2)ccc1O</smiles>

131<smiles>CCCCCCCCCCCCCCCCCC</smiles>

132<smiles>[R20]Oc1ccc([C@H]2C(=O)OC[C@H]2c2ccc([R3])c([R2])c2)cc1[R]</smiles>

\begin{tabular}{|c|c|c|c|c|}
\hline & & $\mathrm{R}_{2}$ & $R_{3}$ & $\mathrm{R}_{4}$ \\
\hline & $\begin{array}{l}\mathrm{CH}_{3} \\
\mathrm{CH}_{3}\end{array}$ & $H$ & $\mathrm{OH}$ & $\mathrm{OCH}_{3}$ \\
\hline & $\mathrm{H}$ & $\mathrm{OCH}_{3}$ & $\mathrm{OH}$ & $\mathrm{OH}$ \\
\hline & $\mathrm{CH}$ & $\mathrm{H}$ & $\mathrm{OCH}_{2} \mathrm{O}$ & $\mathrm{OCH}_{2} \mathrm{O}$ \\
\hline & $\mathrm{H}$ & $\mathrm{H}$ & $\mathrm{OCH}_{2} \mathrm{O}$ & $\mathrm{OCH}_{2} \mathrm{O}$ \\
\hline & $\begin{array}{l}\mathrm{H} \\
\mathrm{H}\end{array}$ & $\begin{array}{l}\mathrm{OCH}_{3} \\
\mathrm{OCH}_{3}\end{array}$ & $\underset{\mathrm{OH}}{\mathrm{OCH}_{2} \mathrm{O}}$ & $\begin{array}{l}\mathrm{OCH}_{2} \mathrm{O} \\
\mathrm{OCH}_{2}\end{array}$ \\
\hline
\end{tabular}

Figure 8. Chemical structures of the lactones in C. cassia. 


\subsection{Other Compounds}

In addition to these major compounds mentioned above, some other chemical compounds are found from C. cassia, including benzyl benzoate (140), 2-hydroxybenzaldehyde (141), 3-phenylpropanol (142) [33], 2,2,4,6,6-pentamethylheptane (143), 2,5,9-trimethyldecane (144), 2-ethyl-5-propylphenol (145), 3,4-dimethoxyphenethyl alcohol (146), 2,5-dimethylundecane (147) [40], benzaldehyde (148), phenylethyl alcohol (149) [33,40], 2-methoxyphenylacetone (150) [35], benzenepropanal (151) [33,35], acetophenone (152) [33,36], 1,3-dimethylbenzene (153), styrene (154), 2,2,4-trimethyl-1,3-pentanediol (155), decanal (156), 2,6,10-trimethyldodecane (157) [36], epicatechin- $(4 \beta \rightarrow 8)$-epicatechin- $(4 \beta \rightarrow 8)$-epicatechin (158) [51], rosavin (159) [42,47], coumarin (160) [36,49], dihydromelilotoside (161), methyl dihydromelilotoside (162) [42], evofolin B (163) [44,47], cinnamomoside A (164) [44], cinncassin C (165) and cinncassin B (166) [46] (Figure 9).

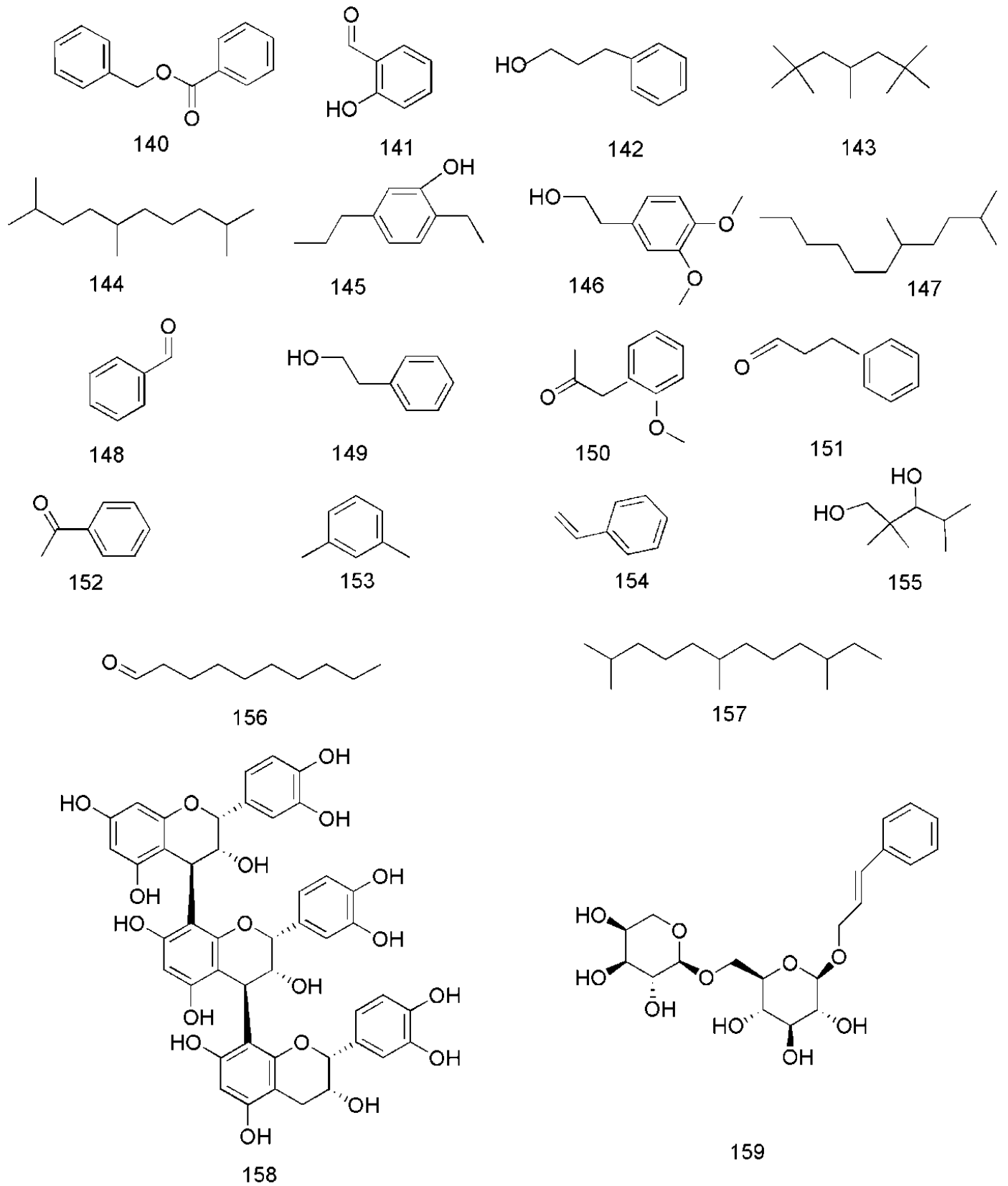

Figure 9. Cont. 
<smiles>O=c1ccc2ccccc2o1</smiles>

160<smiles>COc1cc(C(=O)C(CO)c2ccc(O)c(OC)c2)ccc1O</smiles>

163<smiles>COc1cc(C(c2cc(OC)c(O)c(OC)c2)[C@H]2C[C@@H](C(=O)O)CO2)cc(OC)c1O</smiles>

165<smiles>O=C(O)CCc1ccccc1OC(Cl)Cl</smiles><smiles>COC(=O)CCc1ccccc1OC(Cl)Cl</smiles>

162<smiles>COC(=O)[C@H]1[C@@H](c2ccc(O)cc2)[C@H](c2ccc(O)cc2)[C@H]1C(=O)OC[C@H]1O[C@H](C)[C@@H](O)[C@H](O)[C@H]1O</smiles><smiles>COc1cc(C2OC[C@H](O)C2c2cc(OC)c(O)c(OC)c2)cc(OC)c1O</smiles>

166

Figure 9. Chemical structures of other compounds found in C. cassia.

\section{Pharmacology}

\subsection{Anti-Tumor Effects}

Histone deacetylases (HDACs) are enzymes which play a special role in tissue development and homeostasis. HDACs are divided into four categories: Class I (HDAC1, 2, 3 and 8); II (HDAC4, 5, 6, 7, 9 and 10); and IV (HDAC11) [55]. Recent studies have shown that HDACs are associated with tumor, cardiovascular, autoimmune and neurodegenerative diseases, and HDAC8 plays an important role in the physiological process of these diseases [56]. Gene knockout of HDAC8 can change the growth of cancer cells, cause cell cycle arrest and differentiation of neuroblastoma cells [57]. Trichostatin A (TSA) is a famous antitumor drug and HDAC inhibitor. In 2017, it was found that the bioactive compounds of water extracts of $C$. cassia (WEC, including cinnamic acid, cinnamaldehyde, and cinnamyl alcohol) bind to the active sites of the HDAC8 enzyme like TSA, and the molecular descriptors of C. cassia compounds and the binding interactions and energies were similar to those of TSA. Moreover the bioactive components of $C$. cassia were easier to synthesize. These studies showed that $C$. cassia is a potential antitumor drug [58]. C. cassia components have been extensively studied in lung cancer, breast cancer, oral cancer, cervical cancer, head and neck squamous cell carcinoma.

Ohnuma et al. studied the inhibitory effect of procyanidins $(0-300 \mu \mathrm{g} / \mathrm{mL})$, bioactive components of C. cassia, against the lung cancer cell lines A549, LK-2, abd LU-99 and the potential mechanisms. It found that procyanidins could activate insulin-like growth factor-1 receptor (IGF-1R) phosphorylation and cysteine protease, inhibit the activity of Nrf2-regulated enzymes and the level of Nrf2 expression in lung cancer cells [59-61].

In 2013, Kin et al. found that procyanidin C1, isolated from the bark of C. cassia, could inhibit TGF- $\beta$-induced epithelial-to-mesenchymal transition (EMT) and cell metastasis in A549 lung cancer cells in a dose-dependent manner [51]. Later, in 2017, it was reported that ethanol extracts of C. cassia (EEC) possess antimetastatic activity against A549 and H1299 cells by inhibiting TGF-b1-induced EMT 
and suppressing A549 tumor growth in vivo [62]. In 2018, Wu et al. reported that EEC can inhibit the metastasis of A549 and H1299 tumor cells by repressing u-PA/MMP-2 via FAK to ERK1/2 pathways, and there was no cytotoxicity at the highest concentration of $60 \mu \mathrm{g} / \mathrm{mL}$ [63]. Furthermore, Lee et al. found that water extracts of twigs of $C$. cassia (WETC) could inhibit the growth of the lung cancer cell lines A549, H1299 and LLC by inhibiting the activity of pyruvate dehydrogenase kinase (PDHK) [64].

In 2016, Chang et al. reported that EOC and cinnamaldehyde could significantly suppress the activity of HSC 3 cells and promote their apoptosis, with half maximal inhibitory concentration $\left(\mathrm{IC}_{50}\right)$ values of 13.7 and $10 \mu \mathrm{g} / \mathrm{mL}$ [65]. Later, in 2018, it was reported that ethanol extracts of twigs of C. cassia (EETC) can induce oral cancer cell death and inhibit nude mice tumor growth by activating caspase-3 and reducing Bcl-2 to induce apoptosis [66].

In 2015, Sima et al. demonstrated that hexane extracts of barks of $C$. cassia (HEBC) can induce apoptosis of MDA-MB-231 and MCF-7 breast cancer cell lines via stimulating the expression of AKT1 in MCF-7 cells and down-regulating the expression in MDA-MB-231 cells. Meanwhile, activation of caspase- 8 is reported for the first time that it is the main apoptotic pathway of $C$. cassia in the treatment of breast cancer [67].

Furthermore, the anti-tumor effects of $C$. cassia on cervical cancers have also been reported in recent years. In 2010, Koppikar et al. reported that water extracts of barks of C. cassia (WEBC) can change the growth kinetics of a cervical cancer cell line (SIHA) and down-regulate MMP-2, decreasing the cell mobility in a dose-dependent manner, WEBC can induce apoptosis of cervical cancer cells by increasing intracellular calcium signal and loss of mitochondrial membrane potential [68].

Additionally, an investigation in 2015 indicated that EOTC can significantly inhibit the growth of different cell lines (FaDu, Detroit-562, SCC-25) of head and neck squamous cell carcinoma (HNSCC) by inhibiting the active site of EGFR-TK, and also significantly inhibit the tumor growth in a Hep-2 cell xenotransplantation model [53].

\subsection{Anti-Inflammatory and Analgesic Effects}

In 2012, it was reported that cinnamaldehyde $(1.25,2.5$ and $5 \mathrm{mg} / \mathrm{kg})$ can decrease paw edema after carrageenan injection, and increase the activities of catalase (CAT), superoxide dismutase (SOD), and glutathione peroxidase (GPx) in the paw tissue. Meanwhile, cinnamic aldehyde $(6.25-50 \mu \mathrm{M})$ significantly inhibited the levels of nitric oxide (NO), tumor necrosis factor (TNF- $\alpha$ ), and prostaglandin E2 (PGE2) levels, blocked protein expression of inducible nitric oxide synthase (iNOS), cyclooxygenase-2 (COX-2), nuclear transcription factor kappa B (NF- $\mathrm{BB}$ ), and I $\mathrm{kB} \alpha$ in Lipopolysaccharide (LPS)-stimulated mouse macrophage (RAW264.7) [69]. In addition, Joung et al. reported that WEBC (20, 100 and $500 \mathrm{mg} / \mathrm{kg}$ ) can significantly decrease the serum levels of LPS-induced TNF- $\alpha$ and interleukin (IL)-6, and WEBC $(10-400 \mu \mathrm{g} / \mathrm{mL})$ can inhibit inflammatory responses in LPS-stimulated mouse peritoneal macrophages via inhibiting the mRNA expression of TNF- $\alpha$ and the activation of JNK, p38 and ERK1/2 [4].

In 2014, Pannee et al. reported that EOLC and cinnamaldehyde $(1.25-20 \mu \mathrm{g} / \mathrm{mL})$ can decrease the production of NO, the levels of monocyte chemoattractant protein-1 (MCP-1), macrophage inflammatory protein- $1 \alpha$ (MIP- $1 \alpha)$, TNF- $\alpha$, IL-1 $\beta$ and IL- 6 , inhibit the expression of COX-2, iNOS and microsomal prostaglandin-E synthase-1 (mPGES-1) in LPS-activated J774A.1 cells ( $\mathrm{IC}_{50}=6.1 \pm 0.25$ and $9.97 \pm 0.35 \mu \mathrm{g} / \mathrm{mL}$, respectively) [34]. A 2015report showed that ethyl acetate extracts of barks of $C$. cassia (EAEBC) can suppress inflammatory responses via the inhibition of NO and TNF- $\alpha$ in LPS-induced RAW 264.7 and J774A.1 macrophages $\left(\mathrm{IC}_{50}=19.7 \pm 6.0 \mu \mathrm{g} / \mathrm{mL}\right.$ and $78.4 \pm 1.5 \mu \mathrm{g} / \mathrm{mL}$, $\mathrm{LC}_{50}=140 \pm 9.0 \mu \mathrm{g} / \mathrm{mL}$ ) [70].

In 2016, Lan et al. demonstrated that EOTC $(15,30$ and $60 \mathrm{mg} / \mathrm{kg})$ can significantly reduce the amount of writhing induced by oxytocin and acetic acid, inhibit the Complete Freund's adjuvant (CFA) and formalin-induced paw flinching and licking, in addition, EOTC also inhibited carrageenan-induced mechanical hyperalgesia and paw edema via inhibiting the levels of TNF- $\alpha$, IL- $1 \beta$, NO and PGE2, and 
depressed the expressions of iNOS and COX-2 in paw skin tissue of mice [52]. In addition, EAEBC was reported to be inhibitory to the production of NO in LPS-induced BV-2 microglial cells [46].

In 2017, Shin et al. reported that ethanol extracts of barks of C. cassia (EEBC) $(25,50$ and $100 \mathrm{mg} / \mathrm{kg})$ can improved the survival rate in the LPS-induced septic shock and gout murine model via inhibiting inflammasome activation including NOD-like receptor 3 (NLRP 3), NLRC4 and interferon-inducible protein AIM2 [71]. Later, cinnamomulactone $(0.1,1,10$ and $100 \mu \mathrm{M})$, a new phytocompound from the EETC, was reported to be inhibitory to the expression of MMP-1, MMP-3 and IL-1 $\beta$ in rheumatoid arthritis synovial fibroblasts [49]. Moreover, in 2018, Sharma et al. reported that WEBC $(50,100$ and $200 \mathrm{mg} / \mathrm{kg}$ ) can significantly reduce IL-1, MDA, TNF- $\alpha$ levels and joint swelling in a concentration-dependent manner in rats with CFA-induced and formaldehyde- induced arthritis [72].

Additionally, C. cassia was confirmed to inhibit some other kinds of painful diseases. Oxaliplatin, a chemotherapeutic drug, can induce cold and mechanical hypersensitivity, but there is still a lack of effective treatments for neuropathic pain without side effects, it has been found that $C$. cassia has an effective analgesic effect on neuropathic pain induced by oxaliplatin [73]. In 2016, Kim et al. reported that WEBC $(100,200$ and $400 \mathrm{mg} / \mathrm{kg})$ have a potent anti-allodynic effect via inhibiting the activation of astrocytes and microglia and decreasing the expression of IL-1 $\beta$ and TNF in the spinal cord after injection with oxaliplatin [74]. Later, In 2019, cinnamic acid (10, 20 and $40 \mathrm{mg} / \mathrm{kg}$ ), a major compound of C. cassia, was reported to provide relief against oxaliplatin-induced neuropathic pain through inhibiting spinal pain transmission [75].

\subsection{Anti-diabetic and Anti-obesity Effects}

In 2006, Kwon et al. found that the WEBC (100, 250 and $500 \mathrm{mg} / \mathrm{kg}$ ) can completely prevent streptozotocin (STZ)-induced diabetes in mice via inhibiting the expression of iNOS and the activation of NF- $\mathrm{kB}$, Moreover, WEBC $(0.125,0.25,0.5$ and $1.0 \mathrm{mg} / \mathrm{mL})$ decreased the production $\mathrm{NO}$ and the expression of iNOS mRNA induced by IL-1 $\beta$ and TNF- $\gamma$, which can completely protect rat insulinoma RINm5F cells against IL-1 $\beta$ and TNF- $\gamma$-induced cytotoxicity [3]. In 2013, Jang et al. found that the polyphenols of $C$. cassia (10 and $50 \mathrm{mg} / \mathrm{kg}$ ) exhibited strong hypoglycemic activity in STZ-induced diabetes mice [76]. A report in 2014 demonstrated that acetone extract of barks of C. cassia (AEBC) showed great potential of decreasing the plasma glucose level via inhibiting rat $\alpha$-glucosidase, maltase and sucrase activity $\left(\mathrm{IC}_{50}=0.474,0.38\right.$ and $0.10 \mathrm{mg} / \mathrm{mL}$ ) [77]. Later, Krishna et al. reported that decoumarinated extracts of C. cassia $(200 \mathrm{mg} / \mathrm{kg})$ can significantly alter the level of blood glucose, serum insulin, lipid distribution and liver antioxidant enzymes in STZ induced diabetic rats [78].

In addition to its hypoglycemic effect, cinnamon can also alleviate some complications of diabetes. In 2013, Luo et al. found that EEBC $(10 \mu \mathrm{M})$ resisted the growth of high-glucose-induced mesangial cells via depressing the expression of IL-6, collagen IV and fibronectin [47]. Moreover, Yan et al. revealed that EEBC $(10,30$ and $50 \mu \mathrm{g} / \mathrm{mL})$ restrained the expression of fibronectin, MCP-1 and IL-6 in highglucose-stimulated mesangial cells [37]. In 2018, the extracts of barks of C. cassia (EBC) was reported to reduce the levels of MDA and NO, increase glutathione peroxidase (GPx) and glutathione (GSH), and down-regulate iNOS in thoracic aorta to prevent chronic complications of experimentally induced type II diabetes [79]. Furthermore, C. cassia silver nanoparticles (CcAgNPS) (5, 10 and $200 \mathrm{mg} / \mathrm{kg}$ ) showed remarkable mitigation of severe distortion of the glomerular network, had a regenerative potential in diabetes-induced kidney damage [80].

In 2016, Lee et al. reported that the extracts of C. cassia (EC) (50, 100 and $200 \mu \mathrm{g} / \mathrm{mL}$ ) boosted lipid storage in white adipocytes and increase the fatty acid oxidation capacity throughout the initiation stage of differentiation, which can prevent obesity-induced type II diabetes [81]. In vivo, WEBC $(100,300 \mathrm{mg} / \mathrm{kg})$ significantly decreased serum levels of glucose, insulin, total cholesterol and ALT, suppressed lipid accumulation in liver, prevented oral glucose tolerance and insulin resistance in obese mice. In vitro, WEBC $(0.1$ and $0.2 \mathrm{mg} / \mathrm{mL})$ increased ATP levels by increasing the mRNA expressions of mitochondrial biogenesis-related factors in C2C12 myoblast [82]. 


\subsection{Antibacterial and Antiviral Effects}

The abuse of antibiotics has led to the emergence of drug-resistant bacteria. Plant essential oils have a wide range of bacteriostatic effects and are rarely suffer from resistance issues. In 2013, Zhao et al. reported that EOBC had notable potent activities against Staphylococcus aureus, Aspergillus niger, Bacillus subtilis, and Escherichia coli with minimum inhibitory concentration (MIC) values of 200, 200, 200 and $100 \mu \mathrm{L} / \mathrm{mL}$, respectively [54]. Later, a study revealed that EOBC exhibited strong activity against Staphylococcus aureus, Escherichia coli, Klebsiella pneumoniae and Pseudomonas aeruginosa with MIC values of $0.28,0.28,0.56$ and $1.11 \mathrm{mg} / \mathrm{mL}$, respectively [83]. In 2014, Sheng et al. found that EOBC significantly inhibited growth of non-O157 STECs (including O26, O45, O103, O111) with MIC values of $0.025 \%(v / v)$ [84]. By using the agar diffusion method, the antibacterial activity of EOBC on Escherichia coli and Staphylococcus was evaluated, and the MIC values were both $1.0 \mathrm{mg} / \mathrm{mL}$ [85]. In 2018, Katy et al. reported that EOC inhibited both Staphylococcus hyicus and Staphylococcus aureus with MIC values of $0.078 \%$ [86]. Moreover, Li et al. revealed that Propionibacterium acnes, Staphylococcus epidermidis and Staphylococcus aureus were very sensitive to EOBC, and the MIC values were 0.156, 0.313 and $0.25 \mu \mathrm{L} / \mathrm{mL}$ [87]. In vitro, the EOC exhibited strong inhibition against Staphylococcus aureus with MIC values of $500 \mu \mathrm{L} / \mathrm{L}$, and it had no inductive effect on the acquisition of stress tolerance in S. aureus [88]. Using the agar disc diffusion assay, the antibacterial activity of EOBC on Escherichia coli, Staphylococcus aureus, and Pseudomonas aeruginosa was evaluated, and the MIC values were 4.88, 4.88, and $19.53 \mu \mathrm{g} / \mathrm{mL}$ [89].

Molecular diversity in plants has helped humans discover many effective drugs, such as quinine in Cinchona succirubra and artemisinin in Artemisia annua, leading to a shift in anti-malaria research focus. In 2016, CcAgNPS was demonstrated that inhibited H7N3 influenza A virus in Vero cells with MIC values of $125 \mu \mathrm{g} / \mathrm{mL}$, and it was found that had no-toxicity to Vero cells at the concentration of $500 \mu \mathrm{g} / \mathrm{mL}$ [90].

\subsection{Cardiovascular Protective Effects}

In 2015, Kwon et al. found that WEBC $(10,30$ and $50 \mu \mathrm{g} / \mathrm{mL})$ inhibited the proliferation of VSMCs via arresting $\mathrm{G}_{0} / \mathrm{G}_{1}$ and down-regulating the expression of cell cycle positive regulatory proteins (p21 and p27), which can improve cardiovascular disease caused by proliferation of vascular smooth muscle cells [91]. Later, WEC $(0-100 \mu \mathrm{g} / \mathrm{mL})$ was demonstrated to inhibit the phosphorylation of ERK, p38 and vascular endothelial growth factor (VEGF) R2, the activation of MMP and VEGF-induced proliferation, migration, invasion, tube formation in cultured human umbilical vein endothelial cells (HUVECs) [92]. Furthermore, in vivo, Wei et al. revealed that WEBC $(750 \mathrm{mg} / \mathrm{kg})$ significantly decreased the serum levels of TG, TC, LDL and BNP shortened the intervals of QRS and P-R, increased the $\mathrm{Ca}^{2+} \mathrm{Mg}^{2+}-\mathrm{ATP}$ enzyme activity and the contents of PCr, ATP and ADP in STZ-induced myocardial injury diabetic rats [93].

\subsection{Cytoprotective Effects}

In 2013, it was reported that C. cassia powder (CP) (2, 10 and $100 \mathrm{mg} / \mathrm{g}$ per feed) protected against gastric ulcers induced by stress, ethanol or $\mathrm{HCl}$ through a cytoprotective mechanism [94]. Later, In 2016, El-Kady et al. found that WEBC $(10-50 \mu \mathrm{g} / \mathrm{mL})$ resisted the cytotoxic effect of cis-diammine dichloroplatinum (CDDP) in vitro via preventing CDDP-induced increased expression of mitochondrial Bax protein, releasing of mitochondrial cytochrome c, caspase-3 activation, DNA fragmentation and generation of ROS, up-regulating expression of the cytoprotective gene (heme oxygenase (HO)-1) [95].

\subsection{Neuroprotective Effects}

Recently, investigations into the neuroprotective effects of C. cassia such as anti-anxiety, cognitive improvement and anti-depressant have been conducted. In 2007, an experimental study on anti-anxiety effects showed that EEBC significantly increased the percentage of entries into and the time spent 
in the open arms in the elevated plus maze (EPM) test via regulating the 5-hydroxytryptamine1A $\left(5-\mathrm{HT}_{1 \mathrm{~A}}\right)$ and $\gamma$-aminobutyric acid (GABA)-ergic system [96]. Further, Jung et al. reported that the anxiolytic-like effects of EEBC $(100,750 \mathrm{mg} / \mathrm{mL})$ were mediated by region-specific changes of $5-\mathrm{HT}_{1 \mathrm{~A}}$ receptors in the dorsal raphe nucleus [97].

In 2011, the WEC was evaluated for cognitive improvement in vitro and in vivo. The results showed that WEC $(1,10$ and $100 \mu \mathrm{g} / \mathrm{mL})$ markedly inhibited the formation of toxic Ab oligomers and prevented the toxicity of Ab on neuronal PC12 cells with the MIC value of $0.7 \mu \mathrm{g} / \mathrm{mL}$. In AD fly model, WEC $(0.75 \mathrm{mg} / \mathrm{mL})$ extend their life, recovered their locomotion defects and totally eliminated tetrameric species of $\beta$-amyloid polypeptide $(\mathrm{A} \beta)$ in their brain. Moreover, WEC $(100 \mu \mathrm{g} / \mathrm{mL})$ marked decreased $56 \mathrm{kDa} A \beta$ oligomers, reduced plaques and improved the cognitive functions in $\mathrm{AD}$ transgenic mice model [98]. Later, In 2017, it was reported that total flavonoids of Cinnamomi Cortex $(20-100 \mu \mathrm{g} / \mathrm{mL})$ enhanced viability of PC12 cell and activity of SOD, alleviated the DNA damage, decreased the expression levels of the Bax/Bcl-2 rate, cl Caspase-9 and the content of MDA in 6-hydroxydopamine injured PC-12 cell [99]. In 2016, the EC was evaluated for anti-depressant in vivo. The results showed that EC ( 25 and $50 \mathrm{mg} / \mathrm{kg}$ ) significantly decreased the immobility time in TST (tail suspension test) and increased the 5-HTP-induced head twitches via rising the levels of serotonin [100].

\subsection{Immunoregulation Effects}

In 2014, Zeng et al. studied the immunoregulation effect of EEBC, the results showed that EEBC $(100 \mu \mathrm{g} / \mathrm{mL})$ inhibited $78.5 \%$ of $\mathrm{T}$ cell proliferation induced by concanavalin A (ConA), moreover, cinncassiol $\mathrm{G}$ and cinnacasol (50 and $100 \mu \mathrm{M})$, two new phytocompounds from Cinnamomi Cortex, significantly inhibited T cell proliferation induced by ConA and B cell proliferation induced by LPS in a dose dependent manner, and had no cytotoxicity in mice lymphocytes [39]. In addition, it is reported that phenolic glycosides of Cinnamomi Cortex $(12.5-200 \mu \mathrm{M})$ inhibited T cell proliferation induced by ConA [48]. Furthermore, In 2017, cinnacasside F (400 $\mu \mathrm{M})$, a new glycosides from Cinnamomi Cortex, inhibited $36.1 \% \mathrm{~T}$ cell proliferation and $20.3 \%$ B cell proliferation [45].

\subsection{Anti-Tyrosinase Activity}

In 2013, Chang et al. found that EOBC and trans-cinnamaldehyde had remarkably anti-tyrosinase activity $\left(\mathrm{IC}_{50}=6.16 \pm 0.04\right.$ and $4.04 \pm 0.08 \mathrm{mg} / \mathrm{mL}$, respectively) [40]. Moreover, Chou et al. reported that EOC $(1.0,2.0,2.5$ and $5.0 \mu \mathrm{g} / \mathrm{mL})$ and trans-cinnamaldehyde $(1.0,2.0$ and $2.5 \mu \mathrm{g} / \mathrm{mL})$ reduced the melanin content and tyrosinase activity of the cells, down-regulated tyrosinase expression without exhibiting cytotoxicity, decreased thiobarbituric acid-reactive substance (TBARS) levels and restored glutathione (GSH) and catalase activity in murine B16 melanoma cells stimulated with $\alpha$-melanocyte-stimulating hormone $(\alpha-\mathrm{MSH})\left(\mathrm{IC}_{50}=6.16 \pm 0.04\right.$ and $4.04 \pm 0.08 \mathrm{mg} / \mathrm{mL}$, respectively) [101].

\subsection{Other Pharmacological Effects}

Apart from the pharmacological effects displayed above, C. cassia also possesses some other activities. In 2012, cinnamaldehyde, 2-methoxycinnamaldehyde, 2-hydroxycinnamaldehyde, cinnamic acid and coniferaldehyde and $O$-coumaric acid isolated from extracts of twigs of C. cassia (ETC) showed significantly inhibitory action on xanthine $\left(\mathrm{IC}_{50}=7.8-36.3 \mu \mathrm{g} / \mathrm{mL}\right)$ [42]. In 2014, the effect of methanol extracts of C. cassia (MEC) on arginase and sexual function were evaluated in vitro and in vivo. The results showed that $\operatorname{MEC}(0.1,1,10$, and $100 \mu \mathrm{g} / \mathrm{mL})$ inhibited arginase activity with an $\mathrm{IC}_{50}$ of $61.72 \pm 2.20 \mu \mathrm{g} / \mathrm{mL}$ in rat corpus cavernosum smooth muscle (CCSM). In addition, MEC $(100 \mathrm{mg} / \mathrm{kg})$ increased smooth muscle level, decreased collagen level in rat penile tissue and increased sexual function of young male rats [102]. Moreover, In 2017, it is reported that methanol extracts of barks of C. cassia (MEBC) (50, 100 and $150 \mathrm{mg} / \mathrm{kg}$ ) aided in the recovery of the antioxidant system as well as protective role in histological damages and some haematological parameters in the rat liver treated with titanium dioxide nanoparticles $\left(\mathrm{TiO}_{2} \mathrm{NPS}\right)$ or titanium dioxide bulk salt $\left(\mathrm{TiO}_{2}\right.$ bulk salt) via increasing the serum level of CAT, decreasing the levels of SOD, lipid peroxidation, alanine 
aminotransaminase (ALT), aspartate aminotransferase (AST) and alkaline phosphatase (ALP)[103]. Later, the effect of EOTC on uterine contraction was evaluated in vitro and in vivo. The results showed that EOTC $(25,50$ and $100 \mu \mathrm{g} / \mathrm{mL})$ inhibited spontaneous uterus contractions in a dose-dependent manner via inhibiting the level of $\mathrm{Ca}^{2+}$ in Myometrial cells $\left(\mathrm{IC}_{50}=361.3 \mu \mathrm{g} / \mathrm{mL}\right.$ ). In addition, EOTC $(15,30$ and $60 \mathrm{mg} / \mathrm{kg})$ reduced oxytocin (OT)-induced writhing responses via decreasing the level of $\mathrm{PGF}_{2 \alpha}, \mathrm{COX}-2$ and phosphorylation of myosin light chain 20 (P-MLC 20) [104].

Visceral leishmaniasis (VL) or kala-azar is the fatal form of leishmaniasis caused by Leishmania donovani, outbreaks in the tropics and subtropics, producing physical and reproductive disabilities and causing an immense death toll of 20,000-40,000 each year, which have made a great impact on society [105]. Despite decades of research, there is no available commercial vaccine against VL and chemotherapy is failing owing to emerging resistance and adverse side effects [106]. In 2019, Afrin et al. found that $\mathrm{EBC}$ showed great anti-promastigote activity through inducing apoptosis in vitro with $\mathrm{IC}_{50}$ values of $33.66 \pm 3.25 \mu \mathrm{g} / \mathrm{mL}$. In addition, EBC (50 and $100 \mathrm{mg} / \mathrm{kg}$ ) showed significant protection against $L$. donovani infected mice and hamsters, the in vivo protection achieved was $80.91 \%$ (liver) and $82.92 \%$ (spleen) in mice and $75.61 \%$ (liver) and $78.93 \%$ (spleen) in hamsters. The results showed that Cinnamomi Cortex had direct antileishmanial activity and non-toxicity in vitro and in vivo [107].

\subsection{Summary of Pharmacologic Effects}

In conclusion, C. cassia has a wide range of pharmacological effects including anti-tumor effects, anti-inflammatory and analgesic effects, anti-diabetic and anti-obesity effects, antibacterial and antiviral effects, cardiovascular protective effects, cytoprotective effects, neuroprotective effects, immunoregulation effects and anti-tyrosinase activity (Table 3). Modern pharmaceutical research mainly focuses on extracts and chemical components, which indicated the prospects of C. cassia in the treatment of such diseases.

Table 3. Pharmacological effects of C. cassia.

\begin{tabular}{|c|c|c|c|c|c|}
\hline Effects & Detail & Extracts/Compounds & Concentration/Dose & In Vivo/In Vitro & Ref. \\
\hline \multirow{11}{*}{ Anti-tumor Effects } & \multicolumn{5}{|c|}{ Lung cancer } \\
\hline & $\begin{array}{l}\text { Inhibiting Nrf2-regulated } \\
\text { enzyme activity and Nrf2 } \\
\text { expression }\end{array}$ & procyanidins & $\begin{array}{l}\text { Cell lines of A549, } \\
\text { 0-300 } \mu \mathrm{g} / \mathrm{mL}\end{array}$ & in vitro & [59] \\
\hline & $\begin{array}{l}\text { Inhibiting Nrf2 expression and } \\
\text { cell proliferation }\end{array}$ & procyanidins & $\begin{array}{l}\text { Cell lines of A549, LK-2 } \\
\text { and LU-99, } 2.5 \mu \mathrm{g} / \mathrm{mL}\end{array}$ & in vitro & [60] \\
\hline & $\begin{array}{l}\text { Inhibiting Nrf2 expression and } \\
\text { activation of IGF-1R } \\
\text { phosphorylation }\end{array}$ & procyanidins & $\begin{array}{l}\text { Cell lines of A549, LU-99, } \\
\qquad 10 \mu \mathrm{g} / \mathrm{mL}\end{array}$ & in vitro & [61] \\
\hline & $\begin{array}{c}\text { Inhibiting TGF- } \beta \text {-induced } \\
\text { EMT }\end{array}$ & $\begin{array}{c}\text { WEBC } \\
\text { procyanidin } \mathrm{C} 1\end{array}$ & $\begin{array}{l}\text { Cell lines of A549, } \\
12.5-200 \mu \mathrm{g} / \mathrm{mL} \\
1.25-40 \mu \mathrm{g} / \mathrm{mL}\end{array}$ & in vitro & [51] \\
\hline & $\begin{array}{c}\text { Inhibiting TGF-b1-induced } \\
\text { EMT }\end{array}$ & $\begin{array}{l}\text { EEC } \\
\text { EEC }\end{array}$ & $\begin{array}{l}\text { Cell lines of A549, } \\
\mathrm{H} 1299,20-60 \mu \mathrm{g} / \mathrm{mL} \\
100,200 \mathrm{mg} / \mathrm{Kg}\end{array}$ & $\begin{array}{l}\text { in vitro } \\
\text { in vivo }\end{array}$ & [62] \\
\hline & $\begin{array}{l}\text { Repressing u-PA/MMP-2 via } \\
\text { FAK to ERK1/2 pathways }\end{array}$ & EEC & $\begin{array}{l}\text { Cell lines of A549, } \\
\mathrm{H} 1299,0-60 \mu \mathrm{g} / \mathrm{mL}\end{array}$ & in vitro & [63] \\
\hline & $\begin{array}{c}\text { Inhibiting the activity of } \\
\text { pyruvate dehydrogenase } \\
\text { kinase (PDHK) }\end{array}$ & WETC & $\begin{array}{c}\text { Cell lines of A549, H1299 } \\
\text { and LLC, } 0-200 \mu \mathrm{g} / \mathrm{mL}\end{array}$ & in vitro & [64] \\
\hline & \multicolumn{5}{|c|}{ Oral cancer } \\
\hline & $\begin{array}{l}\text { Cytotoxic effects on HSC-3 } \\
\text { cells }\end{array}$ & $\begin{array}{c}\text { EOC } \\
\text { cinnamaldehyde }\end{array}$ & $\begin{array}{c}\text { HSC }-3 \text { cell line, } \\
2.5-40 \mu \mathrm{g} / \mathrm{mL}, \\
\mathrm{IC}_{50}=13.7 \mu \mathrm{g} / \mathrm{mL} \\
2.5-40 \mu \mathrm{g} / \mathrm{mL} \\
\mathrm{IC}_{50}=10 \mu \mathrm{g} / \mathrm{mL}\end{array}$ & in vitro & [65] \\
\hline & $\begin{array}{l}\text { Enhancement of autophagy } \\
\text { markers to induce cell } \\
\text { apoptosis }\end{array}$ & EETC & $\begin{array}{c}0-100 \mu \mathrm{g} / \mathrm{mL} \\
250,500 \mathrm{mg} / \mathrm{Kg}\end{array}$ & $\begin{array}{l}\text { in vitro } \\
\text { in vivo }\end{array}$ & [66] \\
\hline
\end{tabular}


Table 3. Cont

\begin{tabular}{|c|c|c|c|c|c|}
\hline Effects & Detail & Extracts/Compounds & Concentration/Dose & In Vivo/In Vitro & Ref. \\
\hline & \multicolumn{5}{|c|}{ Breast cancer } \\
\hline & $\begin{array}{l}\text { Cytotoxic effects on MCF-7 } \\
\text { and MDA-MB-231 }\end{array}$ & HEBC & $\begin{array}{l}\text { Cell lines of MCF-7 and } \\
\text { MDA-MB-231, 50, 100, } 200 \\
\mu \mathrm{g} / \mathrm{mL}, \mathrm{IC}_{50}=34 \mu \mathrm{g} / \mathrm{mL} \\
\mathrm{IC}_{50}=32.42 \mu \mathrm{g} / \mathrm{mL}\end{array}$ & in vitro & [67] \\
\hline & \multicolumn{5}{|c|}{ Cervical cancers } \\
\hline & \multicolumn{5}{|c|}{ Head and neck squamous cell carcinoma (HNSCC) } \\
\hline & Inhibiting EGFR-TK activity & EOTC & $0.625-10 \mu \mathrm{g} / \mathrm{mL}$ & in vivo & [53] \\
\hline \multirow{7}{*}{$\begin{array}{c}\text { Anti-Inflammatory } \\
\text { and Analgesic } \\
\text { Effects }\end{array}$} & $\begin{array}{l}\text { Inhibiting LPS-stimulated } \\
\text { inflammatory and } \\
\text { carrageenan induced hind } \\
\text { paw edema }\end{array}$ & cinnamaldehyde & $\begin{array}{c}\text { murine macrophage cell } \\
\text { line RAW264.7, } \\
6.25-50 \mu \mathrm{M} \\
1.25,2.5 \text { and } 5 \mathrm{mg} / \mathrm{kg}\end{array}$ & $\begin{array}{l}\text { in vitro } \\
\text { in vivo }\end{array}$ & [69] \\
\hline & $\begin{array}{l}\text { Inhibiting LPS-stimulated } \\
\text { inflammatory }\end{array}$ & $\begin{array}{c}\text { EOLC } \\
\text { cinnamaldehyde }\end{array}$ & $\begin{array}{c}\text { Macrophage J774A.1 cells, } \\
1.25-20 \mu \mathrm{g} / \mathrm{mL}, \mathrm{IC}_{50}=6.1 \\
\pm 0.25 \mu \mathrm{g} / \mathrm{mL} \\
\mathrm{IC}_{50}=9.97 \pm 0.35 \mu \mathrm{g} / \mathrm{mL}\end{array}$ & in vitro & [34] \\
\hline & $\begin{array}{l}\text { Inhibitory effects on NO } \\
\text { production and TNF- } \alpha\end{array}$ & EAEBC & $\begin{array}{c}\text { RAW } 264.7 \text { and J774A.1 } \\
\text { macrophages, } \mathrm{IC}_{50}=19.7 \\
\pm 78.4 \mu \mathrm{g} / \mathrm{mL}, \mathrm{LC}_{50}=140 \\
\pm 9.0 \mu \mathrm{g} / \mathrm{mL}\end{array}$ & in vitro & [70] \\
\hline & $\begin{array}{l}\text { Inhibiting carrageenan } \\
\text { induced hind paw Edema, } \\
\text { oxytocin and acetic } \\
\text { acid-induced abdominal } \\
\text { constriction test }\end{array}$ & EOTC & 15,30 , and $60 \mathrm{mg} / \mathrm{kg}$ & in vivo & [52] \\
\hline & $\begin{array}{c}\text { Inhibiting Complete Freund's } \\
\text { adjuvant (CFA)-induced } \\
\text { arthritis }\end{array}$ & WEBC & 50,100 and $200 \mathrm{mg} / \mathrm{kg}$ & in vivo & [72] \\
\hline & $\begin{array}{c}\text { Inhibitory effects against } \\
\text { Oxaliplatin-Induced } \\
\text { Neuropathic Cold Allodynia }\end{array}$ & $\begin{array}{l}\text { WEBC } \\
\text { coumarin }\end{array}$ & $\begin{array}{c}100,200 \text { and } 400 \mathrm{mg} / \mathrm{kg} \\
10 \mathrm{mg} / \mathrm{kg}\end{array}$ & in vivo & [74] \\
\hline & $\begin{array}{l}\text { Inhibitory effects against } \\
\text { oxaliplatin-induced } \\
\text { neuropathic cold allodynia }\end{array}$ & cinnamic acid & 10,20 and $40 \mathrm{mg} / \mathrm{kg}$ & in vivo & {$[75]$} \\
\hline \multirow{6}{*}{$\begin{array}{l}\text { Anti-diabetic and } \\
\text { obesity effect }\end{array}$} & $\begin{array}{c}\text { Exhibiting potent } \\
\text { hypoglycemic activity }\end{array}$ & WEBC & $\begin{array}{c}100,250 \text { and } 500 \mathrm{mg} / \mathrm{kg} \\
\text { insulinoma RINm5F cells, } \\
0.125,0.25,0.5 \text { and } 1.0 \\
\mathrm{mg} / \mathrm{mL}\end{array}$ & $\begin{array}{l}\text { in vivo } \\
\text { in vitro }\end{array}$ & [3] \\
\hline & $\begin{array}{c}\text { Exhibiting potent } \\
\text { hypoglycemic activity }\end{array}$ & polyphenols & 10 and $50 \mathrm{mg} / \mathrm{kg}$ & in vivo & [76] \\
\hline & $\begin{array}{l}\text { Inhibiting } \alpha \text {-glucosidase, } \\
\text { Sucrase and Maltase }\end{array}$ & AEBC & $\begin{array}{l}\mathrm{IC}_{50}=0.474 \mathrm{mg} / \mathrm{mL} \\
\mathrm{IC}_{50}=0.10 \mathrm{mg} / \mathrm{mL} \\
\mathrm{IC}_{50}=0.38 \mathrm{mg} / \mathrm{mL}\end{array}$ & in vitro & [77] \\
\hline & $\begin{array}{c}\text { Exhibiting potent } \\
\text { hypoglycemic activity }\end{array}$ & $\begin{array}{l}\text { de-coumarinated } \\
\text { extracts }\end{array}$ & $200 \mathrm{mg} / \mathrm{kg}$ & in vivo & {$[78]$} \\
\hline & $\begin{array}{c}\text { Inhibiting diabetic } \\
\text { nephropathy }\end{array}$ & EEBC & Rat mesangial cells, $10 \mu \mathrm{M}$ & in vitro & [47] \\
\hline & $\begin{array}{c}\text { Inhibiting diabetic } \\
\text { nephropathy }\end{array}$ & EEBC & $\begin{array}{c}\text { Rat mesangial cells, } 10,30 \\
\text { and } 50 \mu \mathrm{g} / \mathrm{mL}\end{array}$ & in vitro & [37] \\
\hline
\end{tabular}


Table 3. Cont

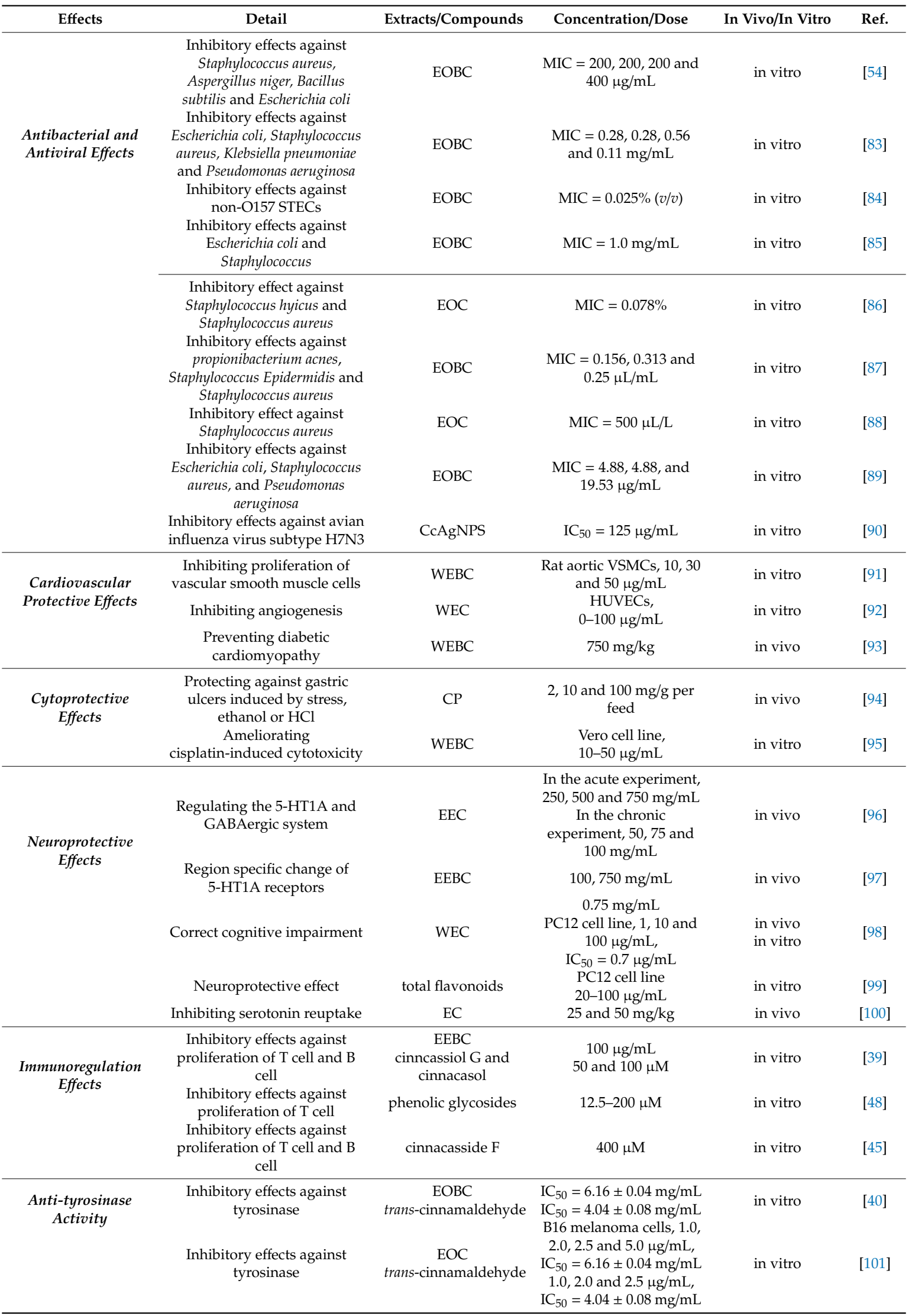


Table 3. Cont.

\begin{tabular}{|c|c|c|c|c|c|}
\hline Effects & Detail & Extracts/Compounds & Concentration/Dose & In Vivo/In Vitro & Ref. \\
\hline \multirow{5}{*}{$\begin{array}{l}\text { Other } \\
\text { Pharmacological } \\
\text { Effects }\end{array}$} & $\begin{array}{l}\text { Inhibitory effects against } \\
\text { xanthine oxidase }\end{array}$ & ETC & $\mathrm{IC}_{50}=7.8-36.3 \mu \mathrm{g} / \mathrm{mL}$ & in vitro & [42] \\
\hline & $\begin{array}{l}\text { Improving sexual function in } \\
\text { young male rats }\end{array}$ & MEC & $\begin{array}{c}0.1,1,10, \text { and } 100 \mu \mathrm{g} / \mathrm{mL} \\
\mathrm{IC}_{50}=61.72 \pm 2.20 \\
\mu \mathrm{g} / \mathrm{mL} \\
100 \mathrm{mg} / \mathrm{kg}\end{array}$ & $\begin{array}{l}\text { in vitro } \\
\text { in vivo }\end{array}$ & [102] \\
\hline & Ameliorating hepatotoxicity & MEBC & $\begin{array}{l}\text { 50, } 100 \text { and } 150 \mathrm{mg} / \mathrm{kg} \\
\text { Myometrial cells, } 15,30\end{array}$ & in vivo & [103] \\
\hline & $\begin{array}{l}\text { Inhibiting spontaneous uterus } \\
\text { contractions }\end{array}$ & EOTC & $\begin{array}{l}\text { and } 60 \mathrm{mg} / \mathrm{kg} \\
25,50 \text { and } 100 \mu \mathrm{g} / \mathrm{mL} \\
\mathrm{IC}_{50}=361.3 \mu \mathrm{g} / \mathrm{mL}\end{array}$ & $\begin{array}{l}\text { in vivo } \\
\text { in vitro }\end{array}$ & [104] \\
\hline & $\begin{array}{l}\text { Inhibitory effect against } \\
\text { Leishmania donovani infection }\end{array}$ & EBC & $\begin{array}{l}\text { Peritoneal macrophages, } \\
\mathrm{IC}_{50}=33.66 \pm 3.25 \\
\mu \mathrm{g} / \mathrm{mL} \\
50 \text { and } 100 \mathrm{mg} / \mathrm{kg}\end{array}$ & $\begin{array}{l}\text { in vitro } \\
\text { in vivo }\end{array}$ & [107] \\
\hline
\end{tabular}

\section{Toxicity}

C. cassia, as a common flavor and medicinal material, has little toxicity, and there are few reports about the toxicity and clinical adverse reactions of $C$. cassia. In 2002, it was reported that a 47 yearold male patient had swelling and itching in both hands and face after touching steamed Cinnamomi cortex for $1 \mathrm{~h}$, while the other two people in the same group were normal. After disengagement, $10 \%$ calcium gluconate $10 \mathrm{~mL}$ and $50 \%$ glucose $20 \mathrm{~mL}$ was given via intravenous injection for 3 days, and the swelling gradually subsided [108]. In 2005, it is reported for the first time that the use of C. cassia essential oil mud bath could cause extensive eczematous and bullous dermatitis [109]. Later, in a randomized controlled trial of $C$. cassia hemoglobin A1C reduction in patients with type 2 diabetes, the treatment group received two C. cassia capsules (500 mg each) per day for 90 days, and one of the subjects developed a rash, which subsided after discontinuation, but no further adverse reactions were observed [110]. In 2018, a 13-week repeat-dose oral toxicity study revealed that body weights of rats were normal, the weight of kidney/live and the level of total cholesterol were increased after receiving WEBC at up to $2000 \mathrm{mg} / \mathrm{kg}$, but it was not mutagenic or clastogenic [111]. Later, a 8-week repeat-dose oral toxicity study revealed that renal function showed a significant increase, kidney and liver histology showed distortions in hepatocytes and sinusoidal linings with infiltrations, degenerative changes in glomerular and Bowman's capsules with fibrillary mesangial interstitium after receiving CcAgNPs at up to $200 \mathrm{mg} / \mathrm{kg}$ [112]. In summary, C. cassia essential oil may cause skin irritation and its extract may possess potential nephrotoxicity and hepatotoxicity at dose higher than its recommended daily safe dose.

\section{Conclusions and Future Perspectives}

In conclusion, the traditional usages, phytochemistry, pharmacological activity and toxicity of C. cassia have been summarized in the present review. Modern studies have confirmed that $C$. cassia has a wide range of pharmacological activities, including anti-tumor effects, anti-inflammatory and analgesic effects, anti-diabetic and anti-obesity effects, antibacterial and antiviral effects, for which it has been used in the clinic in many countries. Moreover, C. cassia has the same origin as a medicine and food which is often used as a condiment in our daily life. Nevertheless, there is still a lack of sufficient research about the alimentotherapy, health products, toxicity and side effects of $C$. cassia. Therefore, more investigations need to be done in C. cassia in the future.

Firstly, there is a lack of systematic toxicity and side effects studies of the extracts or compounds isolated from C. cassia. Essential oils are the main constituents of C. cassia, which has been reported to irritate the skin and possibly cause allergies, and the antibacterial effect of essential oil is applied in food and cosmetics. In addition, as a plant with the same origin as medicine and food, people will also eat $C$. cassia for a long time, therefore, in-depth investigations on its toxicity and side effects are a guarantee for the safe use of this plant. Secondly, with the attention humans attach to health preservation, 
alimentotherapy and health care products are being more and more widely used, thus, there is great space for the development of valuable $C$. cassia health products. Thirdly, for traditional medicinal uses, the bark and twigs of $C$. cassia are important components of traditional Chinese medicine formula, such as Guifu-lizhong pills [113], Guizhi-shaoyao-zhimu decoction [114], thus current pharmacological activity studies of $C$. cassia have mainly focused on its barks and twigs, and there are few investigations on the leaves, fruits and other parts of $C$. cassia. Thus the study on other parts of $C$. cassia may be helpful to the development of alternative medicines and new drugs. Fourthly, the bark is an important part of the tree body, which can maintain the temperature, prevent diseases and pests, its main function is to transport nutrients for the tree body. The barks of $C$. cassia are officially recognized as Rou-Gui in the CH.P (2015 Edition), but many other Cinnamomum species such as Cinnamomum zeylanicum and Cinnamomum burmannii Blume, are used as C. cassia alternatives in many countries. Therefore, the plant morphology, chemical compositions and pharmacological activities should be used to differentiate the different varieties, and it is important to safeguard the efficacy of $C$. cassia to ensure its suitability and security for clinical use. Fifthly, the C. cassia was traditionally used in the treatment of dyspepsia, gastrointestinal diseases, irregular menstruation and arthritis, etc., but not all of these uses had been confirmed by modern preliminary studies. The discovery of artemisinin was based on a classical Chinese medical monograph, therefore the traditional uses in classical monographs should be reasonably developed, and more potential pharmacological activity of $C$. cassia might be explored in the future.

Author Contributions: Conceptualization, Z.C. and L.Y.; writing—original draft preparation, C.Z., L.F., S.F., J.W., T.L., Y.T.; writing — review and editing, Z.C. and L.Y.

Funding: This research received no external funding.

Conflicts of Interest: The authors declare no conflict of interest

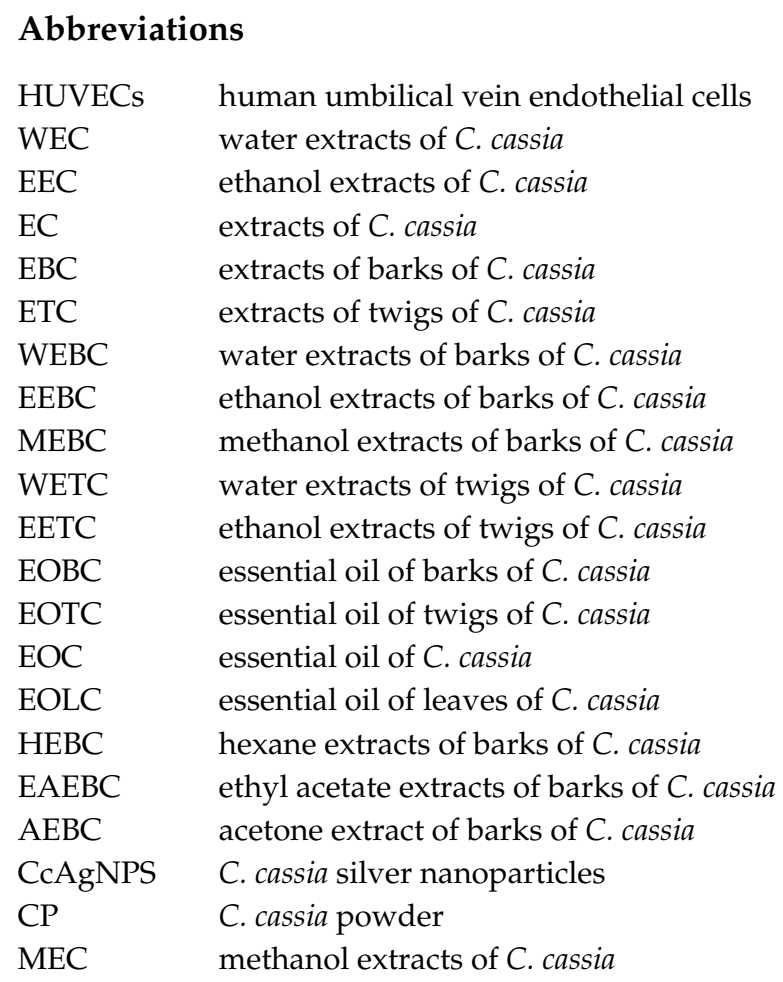




\section{References}

1. Wang, Y.H.; Avula, B.; Nanayakkara, N.P.D.; Zhao, J.P.; Khan, I.A. Cassia Cinnamon as a Source of Coumarin in Cinnamon-Flavored Food and Food Supplements in the United States. J. Agric. Food Chem. 2013, 61, 4470-4476. [CrossRef] [PubMed]

2. Chinese Pharmacopoeia Commission. Pharmacopoeia of the People's Republic of China Part I; People's Medical Publishing House: Beijing, China, 1963; p. 107. (In Chinese)

3. Kwon, K.B.; Kim, E.K.; Jeong, E.S.; Lee, Y.H.; Lee, Y.R.; Park, J.W.; Ryu, D.G.; Park, B.H. Cortex cinnamomi extract prevents streptozotocin- and cytokine-induced $\beta$-cell damage by inhibiting NF- $\mathrm{kB}$. World J. Gastroenterol. 2006, 12, 4331-4337. [CrossRef] [PubMed]

4. Hong, J.W.; Yang, G.E.; Kim, Y.B.; Eom, S.H.; Lew, J.H.; Kang, H. Anti-inflammatory activity of cinnamon water extract in vivo and in vitro LPS-induced models. BMC Complement. Altern. Med. 2012, $12,237$. [CrossRef] [PubMed]

5. Ji, H.Y.; Zeng, F.X.; Zhu, R.X.; Zheng, Z.H. Exploration about the Clinical Application and Dosage of Cinnamon. Jilin J. Tradit. Chin. Med. 2019, 39, 317-320.

6. Lin, H.Q.; Zhou, B.S.; Tan, J.; Wang, H.; Wu, F.L.; Liu, J.P.; Li, P.Y. Research Progress on Chemical Constituents, Pharmacological Activity and Clinical Application of Cinnamomi Cortex. Spec. Wild Econ. Anim. Plant Res. 2018, 40, 65-69.

7. Pharmacopoeia Committee of the Ministry of Health. Drug Specifications Promulgated by the Ministry of Public Health, PR China. The Preparation of Traditional Chinese Drug, Vol. 1; Ministry of Health, PRC: Beijing, China, 1990; p. 160. (In Chinese)

8. Pharmacopoeia Committee of the Ministry of Health. Pharmaceutical Standards of the Ministry of Health (Tibetan Pharmaceutical Branch); People's Health Publishing House: Beijing, China, 1964; p. 8377. (In Chinese)

9. Pharmacopoeia Committee of the Ministry of Health. Drug Specifications Promulgated by the Ministry of Public Health, PR China. The Preparation of Traditional Chinese Drug, Vol. 5; Ministry of Health, PRC: Beijing, China, 1993; p. 2. (In Chinese)

10. Chinese Pharmacopoeia Commission. Pharmacopoeia of the People's Republic of China Part I; People's Medical Publishing House: Beijing, China, 2015; p. 1332. (In Chinese)

11. State Drug Administration. National Standards for Chinese Patent Medicine of the State Drug Administration (Nei Ke Pi Wei Branch); People's Medical Publishing House: Beijing, China, 2002; p. 385. (In Chinese)

12. Chinese Pharmacopoeia Commission. Pharmacopoeia of the People's Republic of China Part I; People's Medical Publishing House: Beijing, China, 2015; p. 453. (In Chinese)

13. Chinese Pharmacopoeia Commission. Pharmacopoeia of the People's Republic of China Part I; People's Medical Publishing House: Beijing, China, 2015; p. 617. (In Chinese)

14. Chinese Pharmacopoeia Commission. Pharmacopoeia of the People's Republic of China Part I; People's Medical Publishing House: Beijing, China, 2015; p. 614. (In Chinese)

15. Chinese Pharmacopoeia Commission. Pharmacopoeia of the People's Republic of China Part I; People's Medical Publishing House: Beijing, China, 2015; p. 844. (In Chinese)

16. State Pharmacopoeia Commission. National Drug Standards for New Drug Correction, Vol. 87; China Pharmaceutical Science and Technology Publishing House: Beijing, China, 2011; p. 4. (In Chinese)

17. State Drug Administration. National Standards for Chinese Patent Medicine of the State Drug Administration (Nei Ke Pi Wei Branch); People's Medical Publishing House: Beijing, China, 2002; p. 496. (In Chinese)

18. State Drug Administration. National Standards for Chinese Patent Medicine of the State Drug Administration (Nei Ke Xin Xi Branch); People's Medical Publishing House: Beijing, China, 2002; p. 91. (In Chinese)

19. State Pharmacopoeia Commission. National Drug Standards for New Drug Correction, Vol. 52; China Pharmaceutical Science and Technology Publishing House: Beijing, China, 2008; p. 40. (In Chinese)

20. Pharmacopoeia Committee of the Ministry of Health. Drug Specifications Promulgated by the Ministry of Public Health, PR China. The Preparation of Traditional Chinese Drug, Vol. 12; Ministry of Health, PRC: Beijing, China, 1997; p. 2. (In Chinese)

21. Chinese Pharmacopoeia Commission. Pharmacopoeia of the People's Republic of China Part I; People's Medical Publishing House: Beijing, China, 2015; p. 449. (In Chinese) 
22. Pharmacopoeia Committee of the Ministry of Health. Drug Specifications Promulgated by the Ministry of Public Health, PR China. The Preparation of Traditional Chinese Drug, Vol. 1; Ministry of Health, PRC: Beijing, China, 1990; p. 101. (In Chinese)

23. Chinese Pharmacopoeia Commission. Pharmacopoeia of the People's Republic of China Part I; People's Medical Publishing House: Beijing, China, 2015; p. 1061. (In Chinese)

24. Chinese Pharmacopoeia Commission. Pharmacopoeia of the People's Republic of China Part I; People's Medical Publishing House: Beijing, China, 2015; p. 1228. (In Chinese)

25. State Pharmacopoeia Commission. National Drug Standards for New Drug Correction, Vol. 52; China Pharmaceutical Science and Technology Publishing House: Beijing, China, 2006; p. 29. (In Chinese)

26. State Pharmacopoeia Commission. National Drug Standards for New Drug Correction, Vol. 64; China Pharmaceutical Science and Technology Publishing House: Beijing, China, 2008; p. 27. (In Chinese)

27. Pharmacopoeia Committee of the Ministry of Healt. Drug Specifications Promulgated by the Ministry of Public Health, PR China. The Preparation of Traditional Chinese Drug, Vol. 18; Ministry of Health, PRC: Beijing, China, 1998; p. 54. (In Chinese)

28. Pharmacopoeia Committee of the Ministry of Health. Drug Specifications Promulgated by the Ministry of Public Health, PR China. The Preparation of Traditional Chinese Drug, Vol. 15; Ministry of Health, PRC: Beijing, China, 1997; p. 43. (In Chinese)

29. Chinese Pharmacopoeia Commission. Pharmacopoeia of the People's Republic of China Part I; People's Medical Publishing House: Beijing, China, 2015; p. 767. (In Chinese)

30. State Pharmacopoeia Commission. National Drug Standards for New Drug Correction, Vol. 32; China Pharmaceutical Science and Technology Publishing House: Beijing, China, 2003; p. 10. (In Chinese)

31. Pharmacopoeia Committee of the Ministry of Health. Drug Specifications Promulgated by the Ministry of Public Health, PR China. The Preparation of Traditional Chinese Drug, Vol. 8; Ministry of Health, PRC: Beijing, China, 1993; p. 7. (In Chinese)

32. Chinese Pharmacopoeia Commission. Pharmacopoeia of the People's Republic of China Part I; People's Medical Publishing House: Beijing, China, 2015; p. 795. (In Chinese)

33. Rao, Z.L.; Xu, F.; Wen, T.Q.; Wang, F.; Sang, W.T.; Zeng, N. Protective effects of essential oils from Rimulus cinnamon on endotoxin poisoning mice. Biomed. Pharmacother. 2018, 101, 304-310. [CrossRef] [PubMed]

34. Pannee, C.; Chandhanee, I.; Wacharee, L. Anti-inflammatory effects of essential oil from the leaves of Cinnamomum cassia and cinnamaldehyde on lipopolysaccharide-stimulated J774A.1 cells. J. Adv. Pharm. Technol. Res. 2014, 5, 164-170. [CrossRef]

35. Xiong, Y.K.; Liu, X.L.; Mu, Z.J.; Yuan, E.; Sun, M.S.; You, Q.T.; Liu, Z.Y. Differences of Chemical Constituents of Volatile Oil from Cinnamomum before and after Drying and Comparison of Anti-Drug Resistant Bacteria Activities. Res. Explor. Lab. 2018, 37, 56-59.

36. Li, Y.Q.; Kong, D.X.; Wu, H. Analysis and evaluation of essential oil components of cinnamon barks using GC-MS and FTIR spectroscopy. Ind. Crop. Prod. 2013, 41, 269-278. [CrossRef]

37. Yan, Y.M.; Fang, P.; Yang, M.T.; Li, N.; Lu, Q.; Cheng, Y.X. Anti-diabetic nephropathy compounds from Cinnamomum cassia. J. Ethnopharmacol. 2015, 165, 141-147. [CrossRef]

38. Pham, V.C.; Nguyen, T.T.A.; Vu, T.O.; Gao, T.Q.; Min, B.S.; Kim, J.A. Five new diterpenoids from the barks of Cinnamomum cassia (L.) J. Presl. Phytochem. Lett. 2019, 32, 23-28. [CrossRef]

39. Zeng, J.F.; Xue, Y.B.; Shu, P.H.; Qian, H.Q.; Sa, R.J.; Xiang, M.; Li, X.N.; Luo, Z.W.; Yao, G.M.; Zhang, Y.H. Diterpenoids with Immunosuppressive Activities from Cinnamomum cassia. J. Nat. Prod. 2014, 77, 1948-1954. [CrossRef] [PubMed]

40. Chang, C.T.; Chang, W.L.; Hsu, J.C.; Shih, Y.; Chou, S.T. Chemical composition and tyrosinase inhibitory activity of Cinnamomum cassia essential oil. Bot. Stud. 2013, 54, 10. [CrossRef] [PubMed]

41. Chen, P.Y.; Yu, J.W.; Lu, F.L.; Lin, M.C.; Cheng, H.F. Differentiating parts of Cinnamomum cassia using LC-qTOF-MS in conjunction with principal component analysis. Biomed. Chromatogr. 2016, 30, 1449-1457. [CrossRef] [PubMed]

42. Ngoc, T.M.; Khoi, N.M.; Ha, D.T.; Nhiem, N.X.; Tai, B.H.; Van Don, D.; Van Luong, H.; Son, D.C.; Bae, K. Xanthine oxidase inhibitory activity of constituents of Cinnamomum cassia twigs. Bioorg. Med. Chem. Lett. 2012, 22, 4625-4628. [CrossRef] [PubMed] 
43. Zhou, W.W.; Liang, Z.T.; Li, P.; Zhao, Z.Z.; Chen, J. Tissue-specific chemical profiling and quantitative analysis of bioactive components of Cinnamomum cassia by combining laser-microdissection with UPLC-Q/TOF-MS. Chem. Cent. J. 2018, 12, 71. [CrossRef]

44. Liu, X.; Fu, J.; Yao, X.J.; Yang, J.; Liu, L.; Xie, T.G.; Jiang, P.C.; Jiang, Z.H.; Zhu, G.Y. Phenolic Constituents Isolated from the Twigs of Cinnamomum cassia and Their Potential Neuroprotective Effects. J. Nat. Prod. 2018, 81, 1333-1342. [CrossRef]

45. Zeng, J.F.; Zhu, H.C.; Lu, J.W.; Hu, L.Z.; Song, J.C.; Zhang, Y.H. Two new geranylphenylacetate glycosides from the barks of Cinnamomum cassia. Nat. Prod. Res. 2017, 31, 1812-1818. [CrossRef]

46. He, S.; Zeng, K.W.; Jiang, Y.; Tu, P.F. Nitric oxide inhibitory constituents from the barks of Cinnamomum cassia. Fitoterapia 2016, 112, 153-160. [CrossRef]

47. Luo, Q.; Wang, S.M.; Lu, Q.; Luo, J.; Cheng, Y.X. Identification of Compounds from the Water Soluble Extract of Cinnamomum cassia Barks and Their Inhibitory Effects against High-Glucose-Induced Mesangial Cells. Molecules 2013, 18, 10930-10943. [CrossRef]

48. Zeng, J.F.; Xue, Y.B.; Lai, Y.J.; Yao, G.M.; Luo, Z.W.; Zhang, Y.H.; Zhang, J.W. A New Phenolic Glycoside from the Barks of Cinnamomum cassia. Molecules 2014, 19, 17727-17734. [CrossRef] [PubMed]

49. Kim, G.J.; Lee, J.Y.; Choi, H.G.; Kim, S.Y.; Kim, E.; Shim, S.H.; Nam, J.W.; Kim, S.H.; Choi, H. Cinnamomulactone, a new butyrolactone from the twigs of Cinnamomum cassia and its inhibitory activity of matrix metalloproteinases. Arch. Pharm. Res. 2017, 40, 304-310. [CrossRef] [PubMed]

50. Li, Z.L.; Cai, Z.C.; Qian, S.H.; Chen, M.H. A New Lactone from the Twigs of Cinnamomum cassia. Chem. Nat. Compd. 2017, 53, 234-236. [CrossRef]

51. Kin, R.; Kato, S.; Kaneto, N.; Sakurai, H.; Hayakawa, Y.; Li, F.; Tanaka, K.; Saiki, I.; Yokoyama, S. Procyanidin C1 from Cinnamomi Cortex inhibits TGF-beta-induced epithelial-to-mesenchymal transition in the A549 lung cancer cell line. Int. J. Oncol. 2013, 43, 1901-1906. [CrossRef]

52. Sun, L.; Zong, S.B.; Li, J.C.; Lv, Y.Z.; Liu, L.N.; Wang, Z.Z.; Zhou, J.; Cao, L.; Kou, J.P.; Xiao, W. The essential oil from the twigs of Cinnamomum cassia Presl alleviates pain and inflammation in mice. J. Ethnopharmacol. 2016, 194, 904-912. [CrossRef]

53. Yang, X.Q.; Zheng, H.; Ye, Q.; Li, R.Y.; Chen, Y. Essential oil of cinnamon exerts anti-cancer activity against head and neck squamous cell carcinoma via attenuating epidermal growth factor receptor-tyrosine kinase. J. BUON 2015, 20, 1518-1525. [PubMed]

54. Zao, D.; Sun, Y.; Chen, G. Inhibition Activity of Cinnamon Oil. J. Jilin Agric. Univ. 2013, 35, 402-405.

55. Jones, P.; Altamura, S.; De Francesco, R.; Gallinari, P.; Lahm, A.; Neddermann, P.; Rowley, M.; Serafini, S.; Steinkuhler, C. Probing the elusive catalytic activity of vertebrate class IIa histone deacetylases. Bioorg. Med. Chem. Lett. 2008, 18, 1814-1819. [CrossRef]

56. Hu, J.; Jing, H.; Lin, H.N. Sirtuin inhibitors as anticancer agents. Future Med. Chem. 2014, 6, 945-966. [CrossRef]

57. Rettig, I.; Koeneke, E.; Trippel, F.; Mueller, W.C.; Burhenne, J.; Kopp-Schneider, A.; Fabian, J.; Schober, A.; Fernekorn, U.; von Deimling, A.; et al. Selective inhibition of HDAC8 decreases neuroblastoma growth in vitro and in vivo and enhances retinoic acid-mediated differentiation. Cell Death Dis. 2015, 6, e1657. [CrossRef]

58. Patil, M.; Choudhari, A.S.; Pandita, S.; Islam, M.A.; Raina, P.; Kaul-Ghanekar, R. Cinnamaldehyde, Cinnamic Acid, and Cinnamyl Alcohol, the Bioactives of Cinnamomum cassia Exhibit HDAC8 Inhibitory Activity: An in vitro and in silico Study. Pharmacogn. Mag. 2017, 13, S645-S651. [CrossRef] [PubMed]

59. Ohnuma, T.; Matsumoto, T.; Itoi, A.; Kawana, A.; Nishiyama, T.; Ogura, K.; Hiratsuka, A. Enhanced sensitivity of A549 cells to the cytotoxic action of anticancer drugs via suppression of Nrf2 by procyanidins from Cinnamomi Cortex extract. Biochem. Biophys. Res. Commun. 2011, 413, 623-629. [CrossRef] [PubMed]

60. Ohnuma, T.; Anzai, E.; Suzuki, Y.; Shimoda, M.; Saito, S.; Nishiyama, T.; Ogura, K.; Hiratsuka, A. Selective antagonization of activated Nrf2 and inhibition of cancer cell proliferation by procyanidins from Cinnamomi Cortex extract. Arch. Biochem. Biophys. 2015, 585, 17-24. [CrossRef] [PubMed]

61. Ohnuma, T.; Sakamoto, K.; Shinoda, A.; Takagi, C.; Ohno, S.; Nishiyama, T.; Ogura, K.; Hiratsuka, A. Procyanidins from Cinnamomi Cortex promote proteasome-independent degradation of nuclear Nrf2 through phosphorylation of insulin-like growth factor-1 receptor in A549 cells. Arch. Biochem. Biophys. 2017, 635, 66-73. [CrossRef] [PubMed] 
62. Lin, C.Y.; Hsieh, Y.H.; Yang, S.F.; Chu, S.C.; Chen, P.N.; Hsieh, Y.S. Cinnamomum cassia extracts reverses TGF-1-induced epithelial-mesenchymal transition in human lung adenocarcinoma cells and suppresses tumor growth in vivo. Environ. Toxicol. 2017, 32, 1878-1887. [CrossRef] [PubMed]

63. Wu, H.C.; Horng, C.T.; Lee, Y.L.; Chen, P.N.; Lin, C.Y.; Liao, C.Y.; Hsieh, Y.S.; Chu, S.C. Cinnamomum Cassia Extracts Suppress Human Lung Cancer Cells Invasion by Reducing u-PA/MMP Expression through the FAK to ERK Pathways. Int. J. Med. Sci. 2018, 15, 115-123. [CrossRef]

64. Lee, E.J.; Chung, T.W.; Lee, J.H.; Kim, B.S.; Kim, E.Y.; Lee, S.O.; Ha, K.T. Water-extracted branch of Cinnamomum cassia promotes lung cancer cell apoptosis by inhibiting pyruvate dehydrogenase kinase activity. J. Pharmacol. Sci. 2018, 138, 146-154. [CrossRef] [PubMed]

65. Chang, W.L.; Cheng, F.C.; Wang, S.P.; Chou, S.T.; Shih, Y. Cinnamomum cassia essential oil and its major constituent cinnamaldehyde induced cell cycle arrest and apoptosis in human oral squamous cell carcinoma HSC-3 cells. Environ. Toxicol. 2017, 32, 456-468. [CrossRef]

66. Yu, C.H.; Chu, S.C.; Yang, S.F.; Hsieh, Y.S.; Lee, C.Y.; Chen, P.N. Induction of apoptotic but not autophagic cell death by Cinnamomum cassia extracts on human oral cancer cells. J. Cell. Physiol. 2019, 234, 5289-5303. [CrossRef]

67. Rad, S.K.; Kanthimathi, M.S.; Abd Malek, S.N.; Lee, G.S.; Looi, C.Y.; Wong, W.F. Cinnamomum cassia Suppresses Caspase-9 through Stimulation of AKT1 in MCF-7 Cells but Not in MDA-MB-231 Cells. PLoS ONE 2015, 10, e0145216. [CrossRef]

68. Koppikar, S.J.; Choudhari, A.S.; Suryavanshi, S.A.; Kumari, S.; Chattopadhyay, S.; Kaul-Ghanekar, R. Aqueous Cinnamon Extract (ACE-c) from the bark of Cinnamomum cassia causes apoptosis in human cervical cancer cell line (SiHa) through loss of mitochondrial membrane potential. BMC Cancer 2010, 10, 210. [CrossRef] [PubMed]

69. Liao, J.C.; Deng, J.S.; Chiu, C.S.; Hou, W.C.; Huang, S.S.; Shie, P.H.; Huang, G.J. Anti-Inflammatory Activities of Cinnamomum cassia Constituents in Vitro and in Vivo. Evid. Based. Complement. Altern. 2012, 2012, 429320. [CrossRef]

70. Gunawardena, D.; Karunaweera, N.; Lee, S.; van der Kooy, F.; Harman, D.G.; Raju, R.; Bennett, L.; Gyengesi, E.; Sucher, N.J.; Munch, G. Anti-inflammatory activity of cinnamon (C-zeylanicum and C-cassia) extracts identification of E-cinnamaldehyde and o-methoxy cinnamaldehyde as the most potent bioactive compounds. Food Funct. 2015, 6, 910-919. [CrossRef] [PubMed]

71. Shin, W.Y.; Shim, D.W.; Kim, M.K.; Sun, X.; Koppula, S.; Yu, S.H.; Kim, H.B.; Kim, T.J.; Kang, T.B.; Lee, K.H. Protective effects of Cinnamomum cassia (Lamaceae) against gout and septic responses via attenuation of inflammasome activation in experimental models. J. Ethnopharmacol. 2017, 205, 173-177. [CrossRef] [PubMed]

72. Sharma, H.; Chauhan, P.; Singh, S. Evaluation of the anti-arthritic activity of Cinnamomum cassia bark extract in experimental models. Integr. Med. Res. 2018, 7, 366-373. [CrossRef] [PubMed]

73. Balayssac, D.; Ferrier, J.; Pereira, B.; Gillet, B.; Petorin, C.; Vein, J.; Libert, F.; Eschalier, A.; Pezet, D. Prevention of oxaliplatin-induced peripheral neuropathy by a polyamine-reduced diet-NEUROXAPOL: Protocol of a prospective, randomised, controlled, single-blind and monocentric trial. BMJ Open 2015, 5, e007479. [CrossRef] [PubMed]

74. Kim, C.; Lee, J.H.; Kim, W.; Li, D.X.; Kim, Y.; Lee, K.; Kim, S.K. The Suppressive Effects of Cinnamomi Cortex and Its Phytocompound Coumarin on Oxaliplatin-Induced Neuropathic Cold Allodynia in Rats. Molecules 2016, 21, 1253. [CrossRef] [PubMed]

75. Chae, H.K.; Kim, W.; Kim, S.K. Phytochemicals of Cinnamomi Cortex: Cinnamic Acid, but not Cinnamaldehyde, Attenuates Axaliplatin-Induced Cold and Mechanical Hypeisensitivity in Rats. Nutrients 2019, 11, 432. [CrossRef]

76. Jiang, Q.; Zou, S.Q.; Zhou, W.H.; Yi, Z.X.; Wu, X.C.; Gong, H.F. Optimization of Extraction Technology for Total Polyphenols from Cinnamomi Cortex and Investigation of its Hypoglycemic Effect. Chin. J. Exp. Med. Formul. 2013, 19, 21-23.

77. Kang, B.H.; Racicot, K.; Pilkenton, S.J.; Apostolidis, E. Evaluation of the in vitro Anti-Hyperglycemic Effect of Cinnamomum cassia Derived Phenolic Phytochemicals, via Carbohydrate Hydrolyzing Enzyme Inhibition. Plant Food Hum. Nutr. 2014, 69, 155-160. [CrossRef]

78. Kumar, I.M.K.; Issac, A.; Ninan, E.; Kuttan, R.; Maliakel, B. Enhanced anti-diabetic activity of polyphenol-rich de-coumarinated extracts of Cinnamomum cassia. J. Funct. Foods 2014, 10, 54-64. [CrossRef] 
79. Uslu, G.A.; Gelen, V.; Uslu, H.; Ozen, H. Effects of Cinnamomum cassia extract on oxidative stress, immunoreactivity of iNOS and impaired thoracic aortic reactivity induced by type II diabetes in rats. Braz. J. Pharm. Sci. 2018, 54. [CrossRef]

80. Kouame, K.; Peter, A.I.; Akang, E.N.; Moodley, R.; Naidu, E.C.; Azu, O.O. Histological and biochemical effects of Cinnamomum cassia nanoparticles in kidneys of diabetic Sprague-Dawley rats. Bosn. J. Basic Med. 2019, 19, 138-145. [CrossRef] [PubMed]

81. Lee, S.G.; Siaw, J.A.; Kang, H.W. Stimulatory Effects of Cinnamon Extract (Cinnamomum cassia) during the Initiation Stage of 3T3-L1 Adipocyte Differentiation. Foods 2016, 5, 83. [CrossRef] [PubMed]

82. Song, M.Y.; Kang, S.Y.; Kang, A.; Hwang, J.H.; Park, Y.K.; Jung, H.W. Cinnamomum cassia Prevents High-Fat Diet-Induced Obesity in Mice through the Increase of Muscle Energy. Am. J. Chin. Med. 2017, 45, 1017-1031. [CrossRef] [PubMed]

83. Pu, Z.H.; Wang, X.Q. Study on antibacterial activity of cinnamon essential oil. J. Mianyang Norm. Univ. 2013, 32, 39-43.

84. Sheng, L.N.; Zhu, M.J. Inhibitory effect of Cinnamomum cassia oil on non-O157 Shiga toxin-producing Escherichia coli. Food Control 2014, 46, 374-381. [CrossRef]

85. Zhang, Y.B.; Liu, X.Y.; Wang, Y.F.; Jiang, P.P.; Quek, S. Antibacterial activity and mechanism of cinnamon essential oil against Escherichia coli and Staphylococcus aureus. Food Control 2016, 59, 282-289. [CrossRef]

86. Vaillancourt, K.; LeBel, G.; Yi, L.; Grenier, D. In vitro antibacterial activity of plant essential oils against Staphylococcus hyicus and Staphylococcus aureus, the causative agents of exudative epidermitis in pigs. Arch. Microbiol. 2018, 200, 1001-1007. [CrossRef] [PubMed]

87. Li, Z.X.; Li, M.; Huang, X.S.; Liang, H.M.; Li, J.L.; Huang, X.H. Study on the bacteriostatic effect of cinnamon oil on acne-inducing bacteria. J. Guangdong Pharm. Univ. 2018, 34, 719-723.

88. Song, X.Q.; Sun, Y.; Zhang, Q.; Yang, X.B.; Zheng, F.; He, S.K.; Wang, Y.F. Failure of Staphylococcus aureus to Acquire Direct and Cross Tolerance after Habituation to Cinnamon Essential Oil. Microorganisms 2019, 7, 18. [CrossRef] [PubMed]

89. El Atki, Y.; Aouam, I.; El Kamari, F.; Taroq, A.; Nayme, K.; Timinouni, M.; Lyoussi, B.; Abdellaoui, A. Antibacterial activity of cinnamon essential oils and their synergistic potential with antibiotics. J. Adv. Pharm. Technol. Res. 2019, 10, 63-67. [CrossRef] [PubMed]

90. Fatima, M.; Zaidi, N.; Amraiz, D.; Afzal, F. In Vitro Antiviral Activity of Cinnamomum cassia and Its Nanoparticles Against H7N3 Influenza a Virus. J. Microbiol. Biotechnol. 2016, 26, 151-159. [CrossRef] [PubMed]

91. Kwon, H.; Lee, J.J.; Lee, J.H.; Cho, W.K.; Gu, M.J.; Lee, K.J.; Ma, J.Y. Cinnamon and its Components Suppress Vascular Smooth Muscle Cell Proliferation by Up-Regulating Cyclin-Dependent Kinase Inhibitors. Am. J. Chin. Med. 2015, 43, 621-636. [CrossRef] [PubMed]

92. Kim, E.C.; Kim, H.J.; Kim, T.J. Water extract of Cinnamomum cassia suppresses angiogenesis through inhibition of VEGF receptor 2 phosphorylation. Biosci. Biotechnol. Biochem. 2015, 79, 617-624. [CrossRef] [PubMed]

93. Wei, K.Z.; Yao, P.A.; Liu, X.N.; Feng, J.H.; Xu, X.; Gao, J.P. Cardioprotective effects of Rougui (Cinnamomi Cortex) on diabetic cardiomyopathy in rats. Shanghai J. Tradit. Chin. Med. 2018, 52, 69-74.

94. Tankam, J.M.; Sawada, Y.; Ito, M. Regular ingestion of cinnamomi cortex pulveratus offers gastroprotective activity in mice. J. Nat. Med. Tokyo 2013, 67, 289-295. [CrossRef] [PubMed]

95. ElKady, A.I.; Ramadan, W.S. The aqueous extract of cinnamon bark ameliorated cisplatin-induced cytotoxicity in vero cells without compromising the anticancer efficiency of cisplatin. Biomed. Pap. 2016, 160, 363-371. [CrossRef]

96. Yu, H.S.; Lee, S.Y.; Jang, C.G. Involvement of 5-HT1A and GABAA receptors in the anxiolytic-like effects of Cinnamomum cassia in mice. Pharmacol. Biochem. Behav. 2007, 87, 164-170. [CrossRef]

97. Jung, Y.H.; Kwon, S.H.; Hong, S.I.; Lee, S.O.; Kim, S.Y.; Lee, S.Y.; Jang, C.G. 5-HT1A receptor binding in the dorsal raphe nucleus is implicated in the anxiolytic-like effects of Cinnamomum cassia. Pharmacol. Biochem. Behav. 2012, 103, 367-372. [CrossRef]

98. Frydman-Marom, A.; Levin, A.; Farfara, D.; Benromano, T.; Scherzer-Attali, R.; Peled, S.; Vassar, R.; Segal, D.; Gazit, E.; Frenkel, D.; et al. Orally Administrated Cinnamon Extract Reduces bAmyloid Oligomerization and Corrects Cognitive Impairment inAlzheimer's Disease Animal Models. PLoS ONE 2011, 6, e16564. [CrossRef] [PubMed] 
99. Zeng, H.J.; He, G.J.; Huang, H.C.; Li, Y. Protective Effect of Total Flavonoids of Cinnamomi Cortex on PC12 Cell Injured by 6-Hydroxydopamine. J. Chin. Med. Mater. 2017, 40, 2936-2940.

100. Zada, W.; Zeeshan, S.; Bhatti, H.A.; Mahmood, W.; Rauf, K.; Abbas, G. Cinnamomum cassia: An implication of serotonin reuptake inhibition in animal models of depression. Nat. Prod. Res. 2016, 30, 1212-1214. [CrossRef] [PubMed]

101. Chou, S.T.; Chang, W.L.; Chang, C.T.; Hsu, S.L.; Lin, Y.C.; Shih, Y. Cinnamomum cassia Essential Oil Inhibits $\alpha$-MSH-Induced Melanin Production and Oxidative Stress in Murine B16 Melanoma Cells. Int. J. Mol. Sci. 2013, 14, 19186-19201. [CrossRef]

102. Goswami, S.K.; Inamdar, M.N.; Jamwal, R.; Dethe, S. Effect of Cinnamomum cassia Methanol Extract and Sildenafil on Arginase and Sexual Function of Young Male Wistar Rats. J. Sex. Med. 2014, 11, 1475-1483. [CrossRef]

103. Shakeel, M.; Jabeen, F.; Iqbal, R.; Chaudhry, A.S.; Zafar, S.; Ali, M.; Khan, M.S.; Khalid, A.; Shabbir, S.; Asghar, M.S. Assessment of Titanium Dioxide Nanoparticles (TiO2-NPs) Induced Hepato toxicity and Ameliorative Effects of Cinnamomum cassia in Sprague-Dawley Rats. Biol. Trace Elem. Res. 2017, 182, 57-69. [CrossRef]

104. Sun, L.; Liu, L.N.; Li, J.C.; Lv, Y.Z.; Zong, S.B.; Zhou, J.; Wang, Z.Z.; Kou, J.P.; Xiao, W. The essential oil from the twigs of Cinnamomum cassia Presl inhibits oxytocin-induced uterine contraction in vitro and in vivo. J. Ethnopharmacol. 2017, 206, 107-114. [CrossRef]

105. Okwor, I.; Uzonna, J. Social and Economic Burden of Human Leishmaniasis. Am. J. Trop. Med. Hyg. 2016, 94, 489-493. [CrossRef]

106. Chappuis, F.; Sundar, S.; Hailu, A.; Ghalib, H.; Rijal, S.; Peeling, R.W.; Alvar, J.; Boelaert, M. Visceral leishmaniasis: What are the needs for diagnosis, treatment and control? Nat. Rev. Microbiol. 2007, 5, 873-882. [CrossRef]

107. Afrin, F.; Chouhan, G.; Islamuddin, M.; Want, M.Y.; Ozbak, H.A.; Hemeg, H.A. Cinnamomum cassia exhibits antileishmanial activity against Leishmania donovani infection in vitro and in vivo. PLoS. Negl. Trop. D 2019, 13, e0007227. [CrossRef]

108. Zhang, Y. 1 case of allergic reaction caused by processing cinnamon. China J. Chin. Mater. Med. 2002, 6, 480.

109. García-Abujeta, J.L.; de Larramendi, C.H.; Berna, J.P.; Palomino, E.M.N. Mud bath dermatitis due to cinnamon oil. Contact Dermat. 2005, 52, 234. [CrossRef] [PubMed]

110. Crawford, P. Effectiveness of Cinnamon for Lowering Hemoglobin A1C in Patients with Type 2 Diabetes: A Randomized, Controlled Trial. J. Am. Board Fam. Med. 2009, 22, 507-512. [CrossRef] [PubMed]

111. Yun, J.W.; You, J.R.; Kim, Y.S.; Kim, S.H.; Cho, E.Y.; Yoon, J.H.; Kwon, E.; Jang, J.J.; Park, J.S.; Kim, H.C.; et al. In vitro and in vivo safety studies of cinnamon extract (Cinnamomum cassia) on general and genetic toxicology. Regul. Toxicol. Pharmacol. 2018, 95, 115-123. [CrossRef] [PubMed]

112. Kouame, K.; Peter, A.I.; Akang, E.N.; Adana, M.; Moodley, R.; Naidu, E.C.; Azu, O.O. Effect of long-term administration of Cinnamomum cassia silver nanoparticles on organs (kidneys and liver) of Sprague-Dawley rats. Turk. J. Biol. 2018, 42, 498-505. [CrossRef]

113. Sheng, H.E.; Wang, H.L. Clinical study of Guifu Lizhong Wan in treating unstable angina pectoris with syndrome of Yang deficiency of heart and kidney. Acta. Chin. Med. 2016, 31, 1182-1185.

114. Zhang, Q.; Peng, W.; Wei, S.J.; Wei, D.N.; Li, R.L.; Liu, J.; Peng, L.Y.; Yang, S.; Gao, Y.Y.; Wu, C.J.; et al. Guizhi-Shaoyao-Zhimu decoction possesses anti-arthritic effects on type II collagen-induced arthritis in rats via suppression of inflammatory reactions, inhibition of invasion \& migration and induction of apoptosis in synovial fibroblasts. Biomed. Pharmacother. 2019, 118, 109367.

(C) 2019 by the authors. Licensee MDPI, Basel, Switzerland. This article is an open access article distributed under the terms and conditions of the Creative Commons Attribution (CC BY) license (http://creativecommons.org/licenses/by/4.0/). 